\title{
Autoreactive T effector memory differentiation mirrors $\beta$ cell function in type 1 diabetes
}

\author{
Lorraine Yeo, ${ }^{1,2}$ Alyssa Woodwyk, ${ }^{3}$ Sanjana Sood, ${ }^{2}$ Anna Lorenc, ${ }^{1}$ Martin Eichmann, ${ }^{1}$ Irma Pujol-Autonell, ${ }^{1}$ Rosella Melchiotti, ${ }^{2}$ \\ Ania Skowera, ${ }^{1}$ Efthymios Fidanis, ${ }^{2}$ Garry M. Dolton, ${ }^{4}$ Katie Tungatt, ${ }^{4}$ Andrew K. Sewell, ${ }^{4}$ Susanne Heck, ${ }^{2}$ Alka Saxena, ${ }^{2}$ \\ Craig A. Beam, ${ }^{3}$ and Mark Peakman ${ }^{1,2,5}$ \\ 1Department of Immunobiology, Faculty of Life Sciences and Medicine, King's College London, London, United Kingdom. ${ }^{2}$ National Institute of Health Research Biomedical Research Centre at Guy's and St \\ Thomas' Hospital and King's College London, London, United Kingdom. ${ }^{3}$ Division of Epidemiology and Biostatistics, Department of Biomedical Sciences, Western Michigan University Homer Stryker M.D. \\ School of Medicine, Kalamazoo, Michigan, USA. ${ }^{4}$ Division of Infection and Immunity and Systems Immunity Research Institute, Cardiff University School of Medicine, Cardiff, United Kingdom. ${ }^{5}$ King's Health \\ Partners Institute of Diabetes, Endocrinology and Obesity, London, United Kingdom.
}

\begin{abstract}
In type 1 diabetes, cytotoxic CD8 ${ }^{+}$T cells with specificity for $\beta$ cell autoantigens are found in the pancreatic islets, where they are implicated in the destruction of insulin-secreting $\beta$ cells. In contrast, the disease relevance of $\beta$ cell-reactive CD8 ${ }^{+}$T cells that are detectable in the circulation, and their relationship to $\beta$ cell function, are not known. Here, we tracked multiple, circulating $\beta$ cell-reactive CD8 ${ }^{+}$T cell subsets and measured $\beta$ cell function longitudinally for 2 years, starting immediately after diagnosis of type 1 diabetes. We found that change in $\beta$ cell-specific effector memory CD8 ${ }^{+}$cells expressing CD57 was positively correlated with C-peptide change in subjects below 12 years of age. Autoreactive CD57+ effector memory CD8 ${ }^{+} \mathrm{T}$ cells bore the signature of enhanced effector function (higher expression of granzyme B, killer-specific protein of $37 \mathrm{kDa}$, and CD16, and reduced expression of CD28) compared with their CD57- counterparts, and network association modeling indicated that the dynamics of $\beta$ cell-reactive $C D 57^{+}$effector memory $C D 8^{+} T$ cell subsets were strongly linked. Thus, coordinated changes in circulating $\beta$ cell-specific $C D 8^{+} \mathrm{T}$ cells within the $\mathrm{CD} 57^{+}$effector memory subset calibrate to functional insulin reserve in type 1 diabetes, providing a tool for immune monitoring and a mechanism-based target for immunotherapy.
\end{abstract}

\section{Introduction}

Type 1 diabetes is an autoimmune disease in which insulin-secreting $\beta$ cells of the pancreatic islets are selectively destroyed $(1,2) . C D 8^{+} \mathrm{T}$ cells are regarded as critical players in mediating $\beta$ cell destruction, for a number of reasons. First, $\mathrm{CD}^{+} \mathrm{T}$ cells dominate the lymphocytic infiltrate observed in the islets of type 1 diabetes patients, and this pathological lesion is associated with upregulation of HLA class I molecules that has the potential to enhance $\mathrm{CD} 8^{+} \mathrm{T}$ cell- $\beta$ cell interactions (3-5). Second, CD8 ${ }^{+} \mathrm{T}$ cells recognizing $\beta$ cell autoantigens that include preproinsulin (PPI), tyrosine phosphatase-like insulinoma antigen (IA2), islet-specific glucose-6-phosphate catalytic subunit-related protein (IGRP), glutamic acid decarboxylase-65 (GAD65), and insulin B chain (InsB) are present in the blood and islets of individuals with type 1 diabetes $(3,6-8)$. And finally, CD $8^{+}$ T cell clones recognizing epitopes of PPI and GAD65 kill isolated $\beta$ cells in vitro, exemplifying the potential for $\mathrm{CD} 8^{+} \mathrm{T}$ cells to constitute major effectors of $\beta$ cell death $(9,10)$.

Thus, at the level of disease pathogenesis, the $\mathrm{CD}^{+} \mathrm{T}$ cell/ HLA class I pathway provides a compelling framework for a mechanistic understanding of $\beta$ cell destruction leading to type 1 diabetes $(9,11,12)$. As a result, considerable effort has been expended to define $\mathrm{CD} 8^{+} \mathrm{T}$ cell epitopes presented by $\beta$ cells, and measure reactivity against them in the peripheral blood,

Conflict of interest: The authors have declared that no conflict of interest exists. Submitted: February 20, 2018; Accepted: May 23, 2018.

Reference information: / Clin Invest. 2018;128(8):3460-3474.

https://doi.org/10.1172/JCl120555. using highly sensitive technologies such as fluorescent, peptideloaded HLA (pHLA) tetramers, which are designed to identify autoreactive $\mathrm{CD}^{+} \mathrm{T}$ cells at single-cell resolution. The major critique of such an approach is that the relationship between tissueinfiltrating and circulating immune cells is poorly defined. At best, if there is programmed recirculation of relevant $\beta$ cellspecific $\mathrm{CD}^{+} \mathrm{T}$ cells, then studying their blood phase would provide a means to understand what is happening in the tissues. At worst, examining circulating $\mathrm{T}$ cells could be entirely misleading, if they bear little or no relation to the relevant tissue pathology. In the absence of an answer to this conundrum, we reasoned that examining the relationship between circulating $\beta$ cellspecific $\mathrm{CD}^{+} \mathrm{T}$ cells and functional insulin-secreting capacity as they change over time would provide an important step toward addressing this knowledge gap. Identification of a relationship between peripheral immune changes and metabolic activity in the target organ would be a major advance in developing the former into surrogate markers for the latter. This could yield useful biomarkers of $\beta$ cell decline and further strengthen the mechanistic link between autoreactive $\mathrm{CD} 8^{+} \mathrm{T}$ cells and disease pathogenesis.

Therefore, in this study we sought to test the hypothesis that the frequency or functional phenotype of circulating $\beta$ cell-specific $\mathrm{CD}^{+} \mathrm{T}$ cells correlates with the rate of decline of functional insulin reserve following diagnosis of type 1 diabetes (13-16). To achieve this and ensure high quality of biological samples and metadata, we made use of a longitudinal collection made over a 2-year period from patients with a new diagnosis of type 1 diabetes who were enrolled into the placebo arms of clinical intervention trials. 


\section{Results}

Specific autoreactive $C D 8^{+} T$ cell subsets correlate with C-peptide change over time. Antigen-specific $\mathrm{CD}^{+} \mathrm{T}$ cells were identified by pHLA class I tetramer staining of peripheral blood mononuclear cell (PBMC) samples from newly diagnosed type 1 diabetes patients collected longitudinally over 2 years at 6-month intervals (see Supplemental Tables 1 and 2 for patient information; supplemental material available online with this article; https://doi. org/10.1172/JCI120555DS1). We characterized the phenotype of $\mathrm{CD}^{+} \mathrm{T}$ cells specific for $5 \beta$ cell antigens (PPI, IA2, InsB, GAD, and IGRP) and, for comparison, 3 viral antigens (influenza, CMV, and EBV) using pHLA class I tetramers (Figure 1 and Table 1). In addition, we analyzed the $\mathrm{T}$ cell subsets within the total $\mathrm{CD} 8^{+} \mathrm{T}$ cell population. As a readout of $\beta$ cell function we used measurements of C-peptide, a by-product of insulin production that is released into the circulation in amounts equimolar with insulin, and is considered a robust surrogate of $\beta$ cell function. Mixed-effects general linear modeling was used to explore whether there was a relationship between $\mathrm{CD}^{+} \mathrm{T}$ cell subsets and C-peptide change over 2 years. For each $\mathrm{CD}^{+} \mathrm{T}$ cell subset analyzed, the model predicted the amount of C-peptide change that would result from a given change in $\mathrm{T}$ cells. We report these data as slopes that are estimates of the average $\mathrm{C}$-peptide loss per unit change in $\mathrm{T}$ cell.

Of the $\beta$ cell-specific $\mathrm{T}$ cell subsets, 5 were found to be positively correlated with C-peptide change (Figure 2A). Strikingly, these were predominantly effector memory $\mathrm{T}$ cell subsets ( 4 of 5) expressing the terminal differentiation marker CD57 (3 of 5), spanning multiple $\beta$ cell specificities (for PPI, GAD, and InsB). Additionally, the IA2-specific transitional memory subset (a phenotype intermediate between central memory and effector memory) was positively correlated with $\mathrm{C}$-peptide change. When data were pooled from all the $\beta$ cell-specific (PPI-, InsB-, IGRP-, IA2-, and GAD-specific) $\mathrm{CD}^{+} \mathrm{T}$ cells examined, the pooled $\beta$ cellspecific $\mathrm{CD} 7^{+}$effector memory $\mathrm{CD} 8^{+} \mathrm{T}$ subset was also positively correlated with C-peptide change.

The positive correlations observed between $\beta$ cell-specific $\mathrm{T}$ cell subsets and C-peptide indicate that C-peptide levels increase as $\mathrm{T}$ cell levels increase, and C-peptide levels fall as T cell levels fall. To illustrate the nature of this relationship, the dynamics of PPI-specific $\mathrm{CD} 7^{+}$effector memory CD ${ }^{+} \mathrm{T}$ cells and predicted C-peptide levels over 2 years are shown for individual patients in Supplemental Figure 1. Interestingly, concomitant increases in C-peptide and $\beta$ cellspecific $\mathrm{CD} 7^{+}$effector memory $\mathrm{CD} 8^{+} \mathrm{T}$ cell levels were observed in several patients at the 6-month visit. This is likely to reflect the "honeymoon period" experienced by some patients after commencing insulin injection, which is characterized by greater C-peptide secretion. This suggests that the functional recovery of $\beta$ cells promotes the appearance of $\mathrm{CD}^{2} 7^{+}$effector memory $\beta$ cell-specific $\mathrm{CD}^{+} \mathrm{T}$ cells in the blood. As illustrated in Supplemental Figure 1, in the majority of subjects, a decrease in $\beta$ cell-specific $\mathrm{CD} 57^{+}$effector memory $\mathrm{CD}^{+} \mathrm{T}$ cells was accompanied by a fall in predicted C-peptide levels. This is consistent with $\beta$ cell destruction mediated by highly cytotoxic T cells, levels of which decline with loss of antigen. Thus the positive relationships observed between $\beta$ cellspecific $\mathrm{CD}^{2} 7^{+}$effector memory $\mathrm{CD}^{+} \mathrm{T}$ subsets and C-peptide change reflect a prototypical antigen-driven immune response during which levels of T cells and their target covary.
The predicted C-peptide change per T cell change for each of the significantly correlated $\beta$ cell-specific T cell populations is given in Figure $2 \mathrm{~A}$ and Table 2, and is calculated as the log $\mathrm{C}$-peptide change from baseline per $1 \%$ increase in $\mathrm{T}$ cells. For example, in the case of PPI-specific $\mathrm{CD}^{2} 7^{+}$effector memory $\mathrm{CD} 8^{+} \mathrm{T}$ cells, a $1 \%$ increase from baseline is associated with a $\log \mathrm{C}$-peptide increase from baseline of 0.206. In this way, the model provides estimates for the effect of $\mathrm{CD}^{+} \mathrm{T}$ cell change on the change in C-peptide levels.

In order to further investigate the link between tissue antigen levels and circulating $\mathrm{T}$ cells, we examined whether the $\mathrm{CD} 8^{+} \mathrm{T}$ cell subsets that were significantly correlated with C-peptide log change from baseline were also correlated with C-peptide levels. We found that the InsB-specific $\mathrm{CD} 57^{+}$effector memory and InsBspecific effector memory $\mathrm{CD}^{+} \mathrm{T}$ cell subsets correlated with absolute C-peptide levels (Supplemental Table 3).

In contrast to the significant associations observed between antigen-specific $\mathrm{CD} 8^{+} \mathrm{T}$ cell subsets and $\mathrm{C}$-peptide change, none of the total $\mathrm{CD} 8^{+} \mathrm{T}$ cell subsets were found to be significantly associated with C-peptide change.

Virus-specific autoreactive $C D 8^{+} T$ cell subsets correlate with $C$-peptide change over time. We observed that 9 virus-specific $\mathrm{T}$ cell subsets were significantly correlated with C-peptide change (Figure 2B and Table 2). In contrast with the positive correlations observed between $\beta$ cell-specific memory $\mathrm{T}$ cell subsets and C-peptide, the majority (7 of 9) of the virus-specific subsets were negatively correlated with $\mathrm{C}$-peptide change, indicating that C-peptide falls as $\mathrm{T}$ cell levels increase, or C-peptide increases as $\mathrm{T}$ cell levels fall. The phenotype of the significantly correlated virus-specific subsets encompassed several T cell subsets, including CMV-specific transitional memory, central memory, effector memory, $\mathrm{CD} 7^{+}$effector memory, and $\mathrm{CD} 57^{-}$effector memory subsets; influenza-specific transitional memory and CD57- effec-

Table 1. HLA-A*02- and HLA-A*24-restricted CD8+ $T$ cell epitopes

\begin{tabular}{|c|c|c|}
\hline Epitope & HLA class I restriction & Sequence \\
\hline $\mathrm{PPI}_{15-24}$ & $A^{*} 02$ & ALWGPDPAAA \\
\hline $\mathrm{PPI}_{3-11}$ & $A^{*} 24$ & LWMRLLPLL \\
\hline${ }_{10-18}^{\operatorname{lns} B}$ & $A^{*} 02$ & HLVEALYLV \\
\hline $\operatorname{lnsB}_{15-24}$ & $A^{*} 24$ & LYLVCGERGF \\
\hline $\mid A-2$ & $A^{*} 02$ & MVWESGCTV \\
\hline $\operatorname{CAD65}_{114-123}$ & $A^{*} 02$ & VMNILLQYVV \\
\hline IGRP $_{265-273}$ & $A^{*} 02$ & VLFGLGFAI \\
\hline Influenza A M1 & $A^{*} 02$ & GILGFVFTL \\
\hline CMV pp65 & $A^{*} 02$ & NLVPMVATV \\
\hline${ }^{C M V}$ pp65 & $A^{*} 24$ & AYAQKIFKIL \\
\hline EBV BMLF1 & $A^{*} 02$ & GLCTLVAML \\
\hline${ }^{\text {EBV BMLF1 }}{ }_{198-206}$ & $A^{*} 24$ & TYPVLEEMF \\
\hline
\end{tabular}



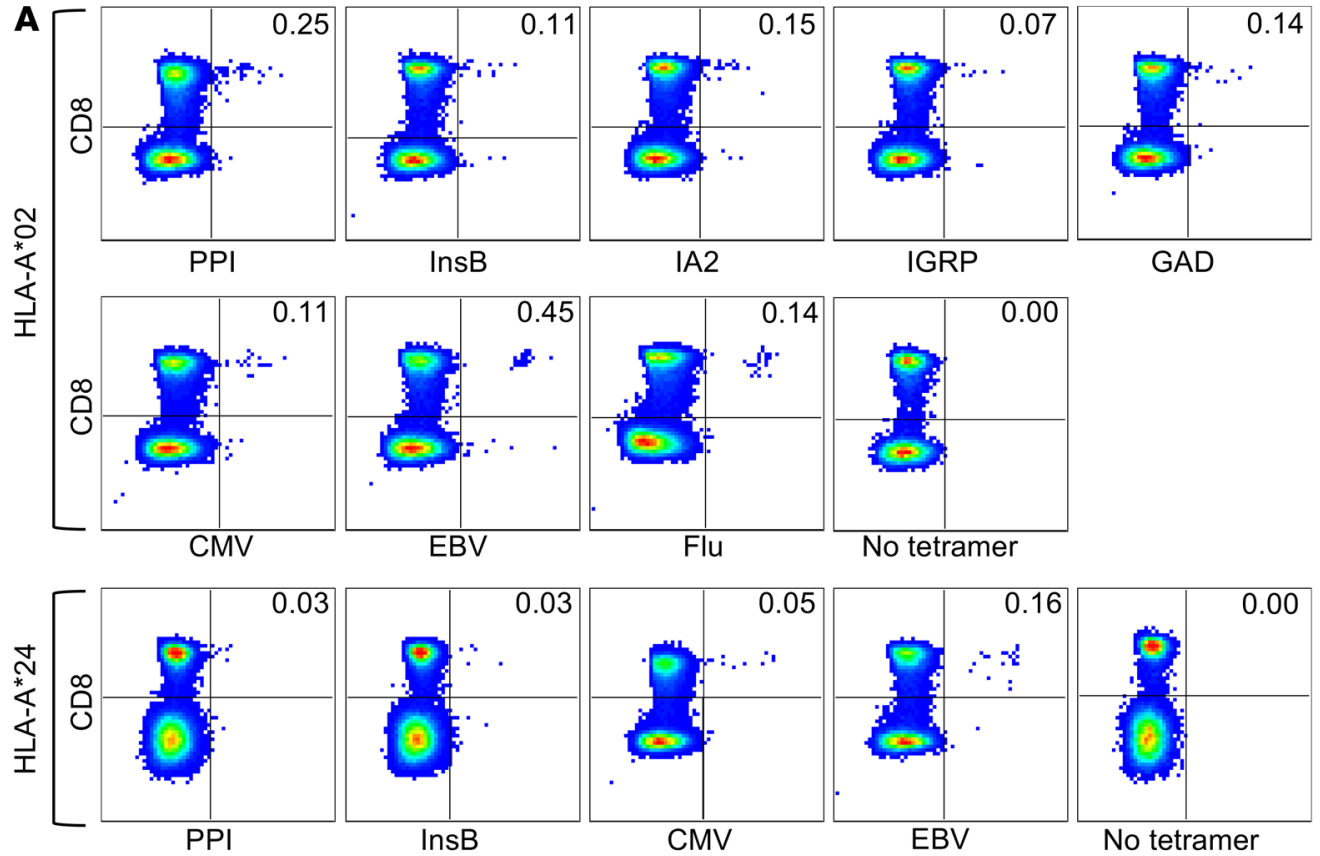

B

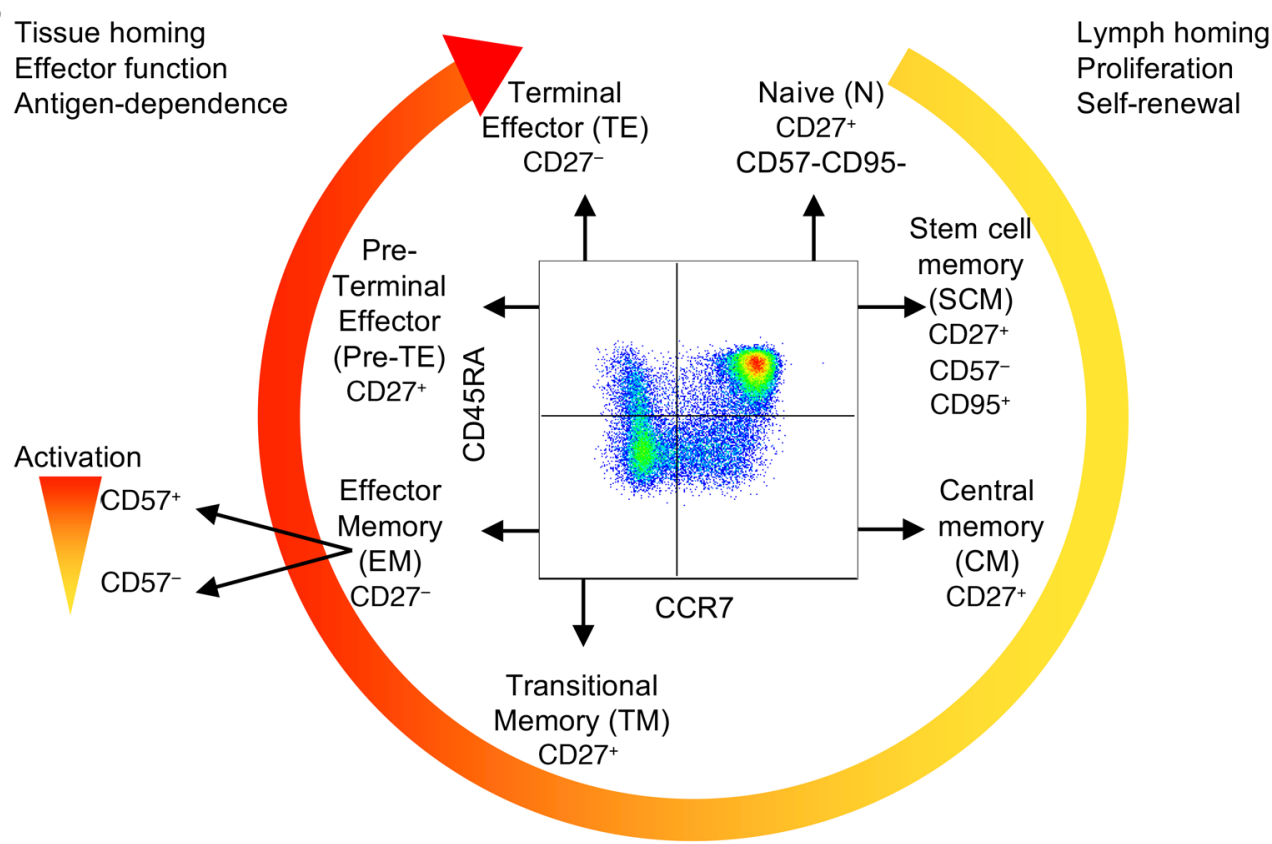

Figure 1. Identification of antigenspecific $\mathrm{CD8}^{+} \mathrm{T}$ cell subsets. (A) Representative staining of PBMCs with peptide-loaded $\mathrm{HLA}-\mathrm{A}^{*} 02$ and $H L A^{*} A-24$ tetramers to identify CD8 ${ }^{+} T$ cells specific for $\beta$ cell and virus epitopes. Tetramer-positive $\mathrm{CD}^{+} \mathrm{T}$ cell frequencies were calculated as the percentage of the total CD8 ${ }^{+} T$ cell population and are displayed in the upper right quadrants of the flow cytometry plots. (B) Schematic of the CD8 ${ }^{+}$ T cell subsets analyzed and the cell surface markers used for their definition. tor memory subsets; and EBV-specific central memory and terminal effector subsets. The predicted C-peptide change per unit increase in $\mathrm{T}$ cells for each of the significantly correlated virusspecific $\mathrm{T}$ cell populations is given in Figure 2B and Table 2.

The phenotypic heterogeneity observed in the significantly correlated virus-specific $\mathrm{T}$ cell subsets contrasts with the clear effector memory-dominant pattern observed for the significantly correlated $\beta$ cell-specific $\mathrm{T}$ cell subsets. It appears likely that this difference reflects the different effects of persistent antigenic exposure (in the case of $\beta$ cells) compared with more complex episodic virus encounters that may occur at different times in different subjects. Importantly, we observed that after adjustment for multiple comparisons, many of the antigen- specific $\mathrm{CD}^{+} \mathrm{T}$ cell subsets remained significantly associated with C-peptide change.

In order to further investigate the link between tissue antigen levels and circulating virus-specific T cells, we examined whether the $\mathrm{CD}^{+} \mathrm{T}$ cell subsets that were significantly correlated with C-peptide log change from baseline were also correlated with C-peptide levels. We found that the CMV transitional memory and CMV effector memory CD8 ${ }^{+} \mathrm{T}$ cell subsets correlated with absolute C-peptide levels (Supplemental Table 3).

Effects of age, HLA, and autoantibodies. We next explored how the relationship between $\mathrm{C}$-peptide and $\mathrm{CD} 8^{+} \mathrm{T}$ cell populations compared between patients of different ages. For this purpose we divided patients into 3 groups of $<12$ years, $12-17$ years, and $>17$ 

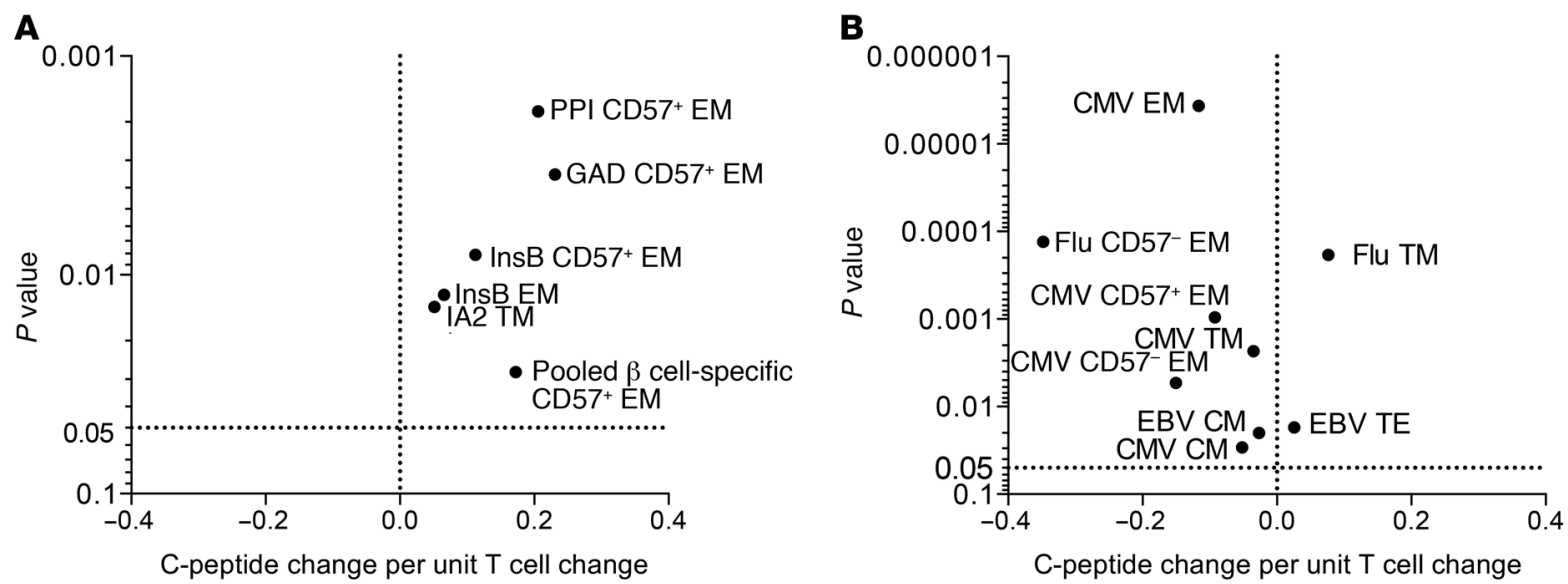

Figure 2. $\beta$ Cell-specific and virus-specific CD8 ${ }^{+}$T cell subsets are significantly correlated with longitudinal C-peptide change. (A) Five $\beta$ cell-specific $\mathrm{CD}^{+} \mathrm{T}$ cell subsets are positively correlated with C-peptide. Additionally, when data are pooled from all $\beta$ cell-specific (PPI-, InsB-, GAD-, IA2-, and CAD-specific) CD8 ${ }^{+} \mathrm{T}$ cells, the CD57 ${ }^{+}$effector memory CD8 ${ }^{+} \mathrm{T}$ subset ("Pooled $\beta$ cell-specific CD57 ${ }^{+}$EM") is positively correlated with C-peptide. (B) Nine virus-specific $\mathrm{CD}^{+} \mathrm{T}$ cell subsets are correlated with longitudinal C-peptide change. Seven of nine are negatively correlated; two are positively correlated. The predicted log C-peptide change from baseline per $1 \%$ increase in each T cell subset is plotted. Thirty-eight subjects were studied, and relationships between $\mathrm{T}$ cell and C-peptide changes from baseline across time were analyzed with mixed-effects general linear models. To understand the variance of these data, note that the $P$ values indicate the standard error, and for $P<0.05$, a $95 \%$ confidence interval would not include the value zero. CM, central memory; TM, transitional memory; EM, effector memory; TE, terminal effector. Relationships between T cell and C-peptide changes from baseline across time were analyzed with mixed-effects general linear models. $P<0.05$ (indicated by dotted horizontal line) was regarded as significant.

years (Supplemental Table 2). Strikingly, it emerged that the relationships observed when all patients were included in the analysis reached statistical significance only in the youngest patient group of $<12$ years but not the older age groups (Supplemental Figure 2 and Table 3). The HLA profiles of the subjects in the 3 age groups were not significantly different $\left(73 \% \mathrm{HLA}^{-} \mathrm{A}^{*} 02\right.$ positive and $27 \%$ HLA-A $^{\star} 24$ positive in the $<12$ years group; $82 \%$ HLA-A $^{\star} 02$ posi-

\section{Table 2. Antigen-specific CD8 ${ }^{+} \mathrm{T}$ cell subsets significantly} correlated with C-peptide

\begin{tabular}{|c|c|c|}
\hline & $\begin{array}{l}\text { C-peptide change } \\
\text { per T cell change }\end{array}$ & $P$ \\
\hline \multicolumn{3}{|l|}{$\beta$ Cell-specific CD8 ${ }^{+} \mathrm{T}$ cell subset } \\
\hline PPI CD57 effector memory & 0.206 & 0.002 \\
\hline CAD $\mathrm{CD} 7^{+}$effector memory & 0.231 & 0.003 \\
\hline InsB CD57+ effector memory & 0.112 & 0.008 \\
\hline InsB effector memory & 0.066 & 0.012 \\
\hline IA2 transitional memory & 0.052 & 0.014 \\
\hline \multicolumn{3}{|l|}{ Virus-specific CD8 ${ }^{+} T$ cell subset } \\
\hline CMV effector memory & -0.116 & $3.7 \times 10^{-6}$ \\
\hline Influenza CD57- effector memory & -0.348 & $1.3 \times 10^{-4}$ \\
\hline Influenza transitional memory & 0.076 & $1.9 \times 10^{-4}$ \\
\hline CMV CD57+ effector memory & -0.092 & 0.001 \\
\hline CMV transitional memory & -0.035 & 0.002 \\
\hline CMV CD57- effector memory & -0.150 & 0.005 \\
\hline EBV terminal effector & 0.026 & 0.017 \\
\hline EBV central memory & -0.027 & 0.020 \\
\hline CMV central memory & -0.052 & 0.029 \\
\hline
\end{tabular}

tive and $18 \%$ HLA-A ${ }^{\star} 24$ positive in the $12-17$ years group; $83 \%$ HLA-A ${ }^{\star} 02$ positive and $17 \%$ HLA-A ${ }^{\star} 24$ positive in the $>17$ years group). The autoantibody profiles were not significantly different between the 3 age groups. In subjects of $<12$ years, $12-17$ years, and $>17$ years, the respective mean and SD autoantibody titers at baseline were 0.25 (0.32), 0.23 (0.30), and 0.36 (0.61) for mIAA; 0.16 (0.14), 0.19 (0.24), and 0.10 (0.11) for GAD65; and $0.33(0.26)$, $0.53(0.46)$, and $0.30(0.35)$ for ICA512.

$\mathrm{CD} 7^{+}$effector memory $\mathrm{CD} 8^{+} \mathrm{T}$ cells have enhanced cytotoxic potential. Having uncovered a strong positive relationship between the $\beta$ cell-specific $\mathrm{CD} 57^{+}$effector memory $\mathrm{CD} 8^{+} \mathrm{T}$ cell subset and $\mathrm{C}$-peptide change, we sought to gain further mechanistic insights by examining the gene expression of the $\mathrm{CD} 57^{+}$effector memory cell subset in comparison with effector memory cells lacking CD57. We performed RNA sequencing of $\mathrm{CD} 7^{+}$and $\mathrm{CD} 57^{-}$effector memory $\mathrm{CD}^{+} \mathrm{T}$ cells sorted from 5 male recent-onset type 1 diabetes patients, and found that 315 genes were differentially expressed between the 2 effector memory populations [FDR-adjusted $P<$ $0.05, \log _{2}$ (fold change) $>1$ ]. Differential gene expression showed consistent patterns across each of the 5 patients analyzed (Figure $3 \mathrm{~A}$ ). As indicated in the volcano plot (Figure 3B), the CD57 ${ }^{+}$ effector memory population showed a significant enrichment of genes associated with cytotoxicity, including granzyme B (GZMB), granzyme $\mathrm{H}(G Z M H)$, killer-specific protein of $37 \mathrm{kDa}$ (KSP37), G protein-coupled receptor 56 (GPR56), and CD16 (17-22), compared with $\mathrm{CD}^{-} 7^{-}$effector memory cells, indicating a gene signature associated with enhanced cytotoxic effector function. Interestingly, the most highly upregulated gene in $\mathrm{CD} 57^{+}$effector memory $\mathrm{CD}^{+} \mathrm{T}$ cells was serine protease 23 (PRSS23), which has been reported in cytotoxic $\mathrm{T}$ cells but whose function remains unknown $(23,24)$. Moreover, in comparison with CD57- effector memory cells, the $\mathrm{CD} 7^{+}$subset showed a relative downregulation of transcripts for the costimulation molecule $C D 28$, and genes 
Table 3. Antigen-specific CD8+ ${ }^{+}$cell subsets associated with C-peptide change in subjects grouped by age

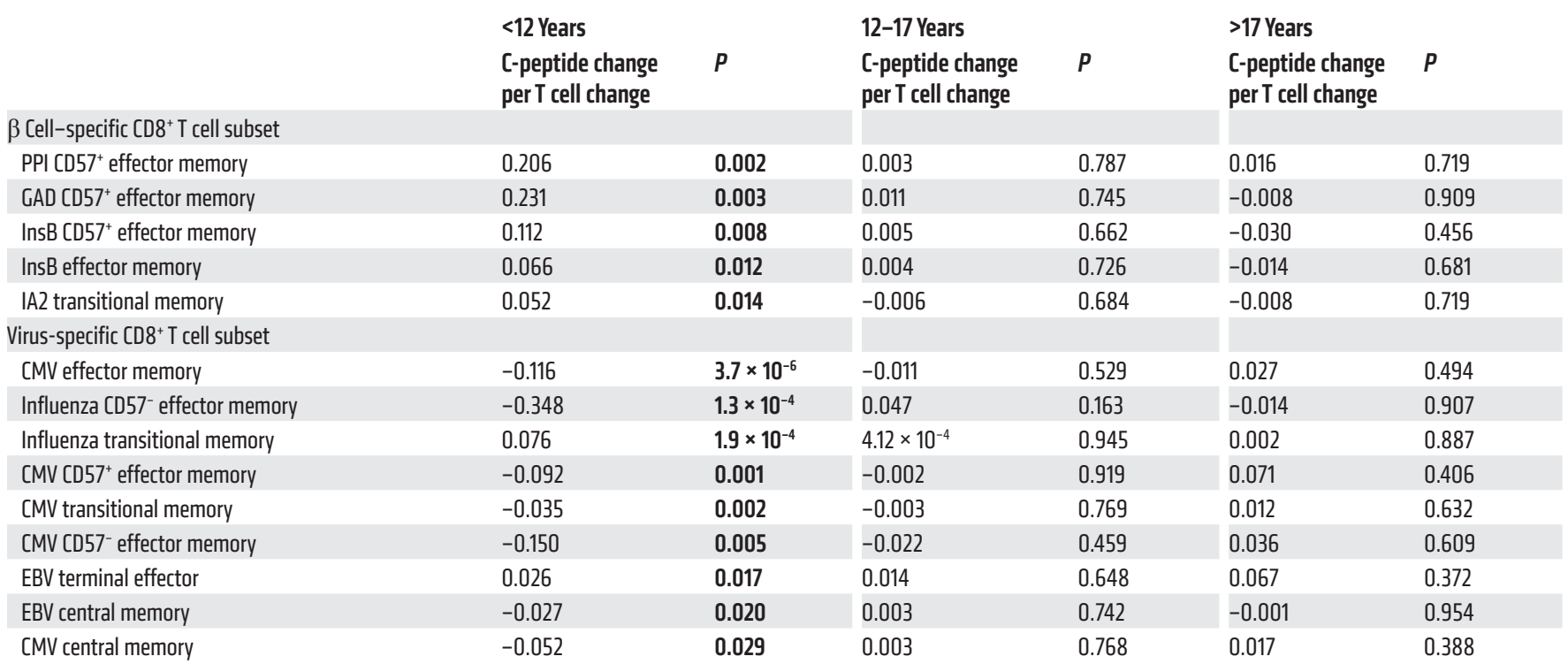

C-peptide change per T cell change was calculated as $\log$ C-peptide change from baseline per $1 \%$ increase in T cells. $P<0.05$ was considered statistically significant.

associated with memory and self-renewal (25-28) including $I L 7 R$, IL2, Satb1, and P2ry14. CD57 ${ }^{+}$effector memory cells showed upregulation of the transcription factor ZEB2, which drives terminal $C D 8^{+} \mathrm{T}$ cell differentiation and represses $I L 2$ and $I L 7 R$ (29). These data indicate that the $\mathrm{CD} 57^{+}$effector memory compartment is a highly differentiated, antigen-experienced population capable of exerting immediate cytotoxic effects, in contrast to the $\mathrm{CD}^{-} 7^{-}$effector memory compartment, which represents a self-renewing pool of memory T cells. The difference in cytotoxic potential between the $\mathrm{CD}_{57^{+}}$and $\mathrm{CD} 57^{-}$effector memory $\mathrm{CD} 8^{+}$ $\mathrm{T}$ cell populations suggested by these data is supported by gene ontology analysis, which reveals significant enrichment of $\mathrm{T}$ cell killing pathways within the genes differentially expressed between $\mathrm{CD}^{+} 7^{+}$and $\mathrm{CD}^{-} 7^{-}$effector memory cells (Figure $3 \mathrm{C}$ ).

To validate these findings at the protein level, and, importantly, to confirm that an enhanced cytotoxic effector gene signature was present in $\beta$ cell-specific $\mathrm{CD} 57^{+}$effector memory CD ${ }^{+} \mathrm{T}$ cells as well as in the total effector memory $\mathrm{CD} 8^{+} \mathrm{T}$ cell pool, we compared the phenotype of PPI-specific CD57 ${ }^{+}$and $\mathrm{CD}^{-} 7^{-}$effector memory T cells in PBMC samples obtained from recent-onset type 1 diabetes patients by flow cytometry. In accordance with the RNA sequencing data, we observed significantly higher expression of granzyme B, GPR56, killer-specific protein of $37 \mathrm{kDa}$, and CD16 and significantly lower expression of CD28 in $\mathrm{CD}^{+} 7^{+}$compared with CD57 ${ }^{-}$effector memory $\mathrm{T}$ cells specific for PPI (Figure 3D). Notably, we confirmed that, as observed from the RNA sequencing data, at the protein level, genes associated with $\mathrm{T}$ cell exhaustion, such as KLRG1 and LAG3, were not upregulated on

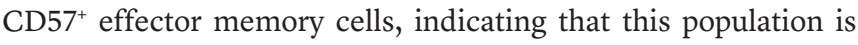
not associated with an exhausted phenotype (Figure 3D). These results suggest that $\beta$ cell-specific $\mathrm{CD} 57^{+}$effector memory $\mathrm{CD} 8^{+}$ $\mathrm{T}$ cells have enhanced cytotoxic potential and are therefore fully capable of driving $\beta$ cell destruction.
$C D 57^{+}$effector memory $C D 8^{+}$T cells show enhanced clonal expansion. To further understand the relationship between the CD57 ${ }^{+}$ and $\mathrm{CD} 7^{-}$effector memory $\mathrm{CD} 8^{+} \mathrm{T}$ cell compartments, we analyzed T cell receptor $\beta$ chain (TCR $\beta$ ) sequences derived from the same RNA sequencing data as that used for gene expression analysis. There were no significant differences in the number of cells sorted or in the number of total TCR $\beta$ sequences obtained from the sorted $\mathrm{CD} 7^{+}$and $\mathrm{CD} 57^{-}$effector memory $\mathrm{CD} 8^{+} \mathrm{T}$ cell populations, allowing unbiased comparison of their TCR $\beta$ repertoires (Supplemental Table 4). Comparison of $\mathrm{CD}^{2} 7^{+}$and $\mathrm{CD}^{-} 7^{-}$effector memory $\mathrm{T}$ cell populations revealed that the diversity of TCR $\beta$ sequences was significantly lower in $\mathrm{CD} 57^{+}$compared with CD57effector memory $\mathrm{T}$ cell samples, indicating a greater enrichment of particular clonotypes in the $\mathrm{CD} 7^{+}$compartment (Figure 4A). Accordingly, in $\mathrm{CD} 7^{+}$effector memory $\mathrm{T}$ cell samples, clones were more highly expanded compared with CD57- effector memory $\mathrm{T}$ cell samples (Figure 4B). In addition, a high level of overlap in TCR $\beta$ sequences was observed between paired $\mathrm{CD} 57^{+}$and $\mathrm{CD}^{-} 7^{-}$effector memory $\mathrm{T}$ cell samples within individual patients, suggesting that both populations have a similar repertoire (Figure $4 \mathrm{C}$ ). This relationship implies that expanded CD $57^{+}$effector memory $\mathrm{T}$ cell clones arise from the $\mathrm{CD}^{-} 7^{-}$effector memory $\mathrm{T}$ cell pool as a result of ongoing or repeated exposures to antigen specificities requiring a cytotoxic response.

Antigen-specific CD8 $8^{+}$cell subsets are associated with each other and with C-peptide change over time. We explored the longitudinal relationships between all of the $\mathrm{CD}^{+} \mathrm{T}$ cell populations analyzed (antigen-specific and total) using cluster analysis based on pairwise correlations of $\mathrm{T}$ cell populations over time. We observed that designated $\mathrm{CD}^{+} \mathrm{T}$ cell subsets cluster together irrespective of their antigen specificity (Figure 5). Notably, we observed that the $\mathrm{CD} 7^{+}$effector memory and total effector memory $\mathrm{T}$ cell subsets with multiple $\beta$ cell specificities were the most strongly clustered 


\section{Table 4. $\beta$ Cell-specific $\mathrm{CD}^{+} \mathrm{T}$ cell subset canonical correlation coefficients}

\begin{tabular}{|c|c|}
\hline CD8 ${ }^{+} \mathrm{T}$ cell population & Canonical correlation coefficient \\
\hline GAD naive & 2.794 \\
\hline GAD pre-terminal effector & 1.905 \\
\hline GAD transitional memory & 1.444 \\
\hline GAD central memory & 1.402 \\
\hline GAD terminal effector & 1.335 \\
\hline IA2 SCM & 0.907 \\
\hline IA2 naive & 0.873 \\
\hline InsB CD57- effector memory & 0.842 \\
\hline IA2 CD57 effector memory & 0.831 \\
\hline IA2 transitional memory & 0.759 \\
\hline IGRP pre-terminal effector & 0.736 \\
\hline CAD CD57+ effector memory & 0.600 \\
\hline InsB central memory & 0.587 \\
\hline InsB pre-terminal effector & 0.584 \\
\hline IGRP naive & 0.465 \\
\hline IA2 central memory & 0.431 \\
\hline InsB naive & 0.408 \\
\hline GAD CD57- effector memory & 0.399 \\
\hline GAD SCM & 0.361 \\
\hline IGRP transitional memory & 0.262 \\
\hline IGRP central memory & 0.192 \\
\hline InsB terminal effector & 0.130 \\
\hline ICRP CD57 $7^{+}$effector memory & 0.099 \\
\hline ICRP terminal effector & -0.006 \\
\hline ICRP CD57- effector memory & -0.045 \\
\hline ICRP SCM & -0.088 \\
\hline InsB CD57+ effector memory & -0.108 \\
\hline IA2 terminal effector & -0.126 \\
\hline IA2 CD57- effector memory & -0.308 \\
\hline InsB SCM & -0.333 \\
\hline PPI terminal effector & -0.338 \\
\hline InsB transitional memory & -0.375 \\
\hline PPI central memory & -0.408 \\
\hline PPI CD57 effector memory & -0.470 \\
\hline IA2 pre-terminal effector & -0.490 \\
\hline PPISCM & -0.549 \\
\hline PPI transitional memory & -0.904 \\
\hline PPI pre-terminal effector & -1.073 \\
\hline PPI CD57- effector memory & -1.121 \\
\hline PPI naive & -1.796 \\
\hline
\end{tabular}

populations, as indicated in Figure 5 by their close proximity and connection by thick green lines representative of strong positive correlations. These observations indicate that the dynamics of $\beta$ cell-reactive $\mathrm{CD}^{+} \mathrm{T}$ cell subsets, including $\mathrm{CD} 57^{+}$effector memory subsets, are correlated during disease progression and may have a synergistic effect in driving $\beta$ cell destruction.

To further explore the relationship between combinations of $\beta$ cell-specific $\mathrm{CD}^{+} \mathrm{T}$ cell subsets and C-peptide, we used canonical correlation analysis. This approach determined the combination of analytes most strongly correlated with C-peptide change from baseline by ascribing weightings to each $\mathrm{T}$ cell subset (canonical correlation coefficients, given in Tables 4-6). For each subject at each visit in the study, we formed a new variable by multiplying each of the $\mathrm{CD}^{+} \mathrm{T}$ cell subset frequencies by the corresponding numerical coefficient and summing these products; thus, the new variable represents a combination of multiple $\mathrm{CD} 8^{+} \mathrm{T}$ cell subset frequencies, referred to as a "canonical correlation score." Canonical correlation analysis was performed using $\beta$ cell-specific CD8 ${ }^{+}$ $\mathrm{T}$ cell data, virus-specific $\mathrm{CD} 8^{+} \mathrm{T}$ cell data, and total $\mathrm{CD}^{+} \mathrm{T}$ cell data. The $\beta$ cell-specific and virus-specific $C D 8^{+} \mathrm{T}$ cell canonical correlation scores were found to correlate strongly with C-peptide (both $r=0.75, P<0.0001$; Figure 6). In contrast, total CD8 ${ }^{+} \mathrm{T}$ cell population canonical correlation scores were much more weakly correlated with C-peptide $(r=0.28, P=0.0005)$. Interestingly, for each of the canonical correlation analyses, the canonical correlation scores exhibited a stronger correlation with $\mathrm{C}$-peptide in subjects of less than 12 years of age, compared with older subjects. Together these results indicate that linked changes in antigenspecific $\mathrm{CD} 8^{+} \mathrm{T}$ cells reflect ongoing activity of the autoimmune process occurring in type 1 diabetes after diagnosis, and that this is most pronounced in the young.

\section{Discussion}

To our knowledge, this is the first study to describe the longitudinal relationship between changes in $\beta$ cell-specific $\mathrm{CD}^{+} \mathrm{T}$ cells and $\beta$ cell function in patients with newly diagnosed type 1 diabetes. Here we show that changes in $\beta$ cell-specific $\mathrm{CD} 57^{+}$effector memory $\mathrm{CD} 8^{+} \mathrm{T}$ cells in the blood reflect concomitant changes in stimulated $\mathrm{C}$-peptide secretion occurring in the target tissue. Thus an expansion of $\beta$ cell-specific $\mathrm{CD}^{2} 7^{+}$effector memory $\mathrm{CD} 8^{+} \mathrm{T}$ cells is associated with $\mathrm{C}$-peptide retention, whereas a reduction of these cells is associated with C-peptide loss. This finding suggests that in the phase of type 1 diabetes that follows diagnosis, the effector memory compartment of the $\beta$ cell-specific $\mathrm{CD}^{+} \mathrm{T}$ cell pool present in the circulation calibrates to changes in $\beta$ cell function. This is an important finding, since it provides evidential support for peripheral blood measurements as indicators of tissue pathology in the setting of a complex autoimmune disease. This relationship is reminiscent of studies of postmortem pancreas samples from recentonset type 1 diabetes patients that reveal that $\mathrm{CD}^{+} \mathrm{T}$ cells are largely retained within the insulin-containing islets, but are absent from insulin-deficient islets (4). These observations in the tissues support the conclusion from our study that antigen load (secreted C-peptide as a measure of $\beta$ cell function) drives the antigenexperienced $\mathrm{CD}^{+} \mathrm{T}$ cell response, and, in particular, tunes the reactivity to expand and retract populations of effector memory cells with gene and protein expression profiles that suggest enhanced cytolytic potential. Interestingly, we observed increases in C-peptide at 6 months in several patients, which were accompanied by increases in $\beta$ cell-specific effector memory $\mathrm{CD}^{2} 7^{+} \mathrm{CD}^{+} \mathrm{T}$ cells. This is likely to reflect the so-called honeymoon period experienced by some patients, during which endogenous $\beta$ cell function recovers and there is greater $\mathrm{C}$-peptide secretion and a reduced requirement for insulin by injection. We speculate that the functional recovery of $\beta$ cells promotes the appearance of $\mathrm{CD} 57^{+}$effector memory $\beta$ cell-specific $\mathrm{CD}^{+} \mathrm{T}$ cells in the blood, via either differentiation or proliferation, resulting in increased $\beta$ cell killing by these cells, which in turns leads to waning of the cytotoxic T cell response. 
A

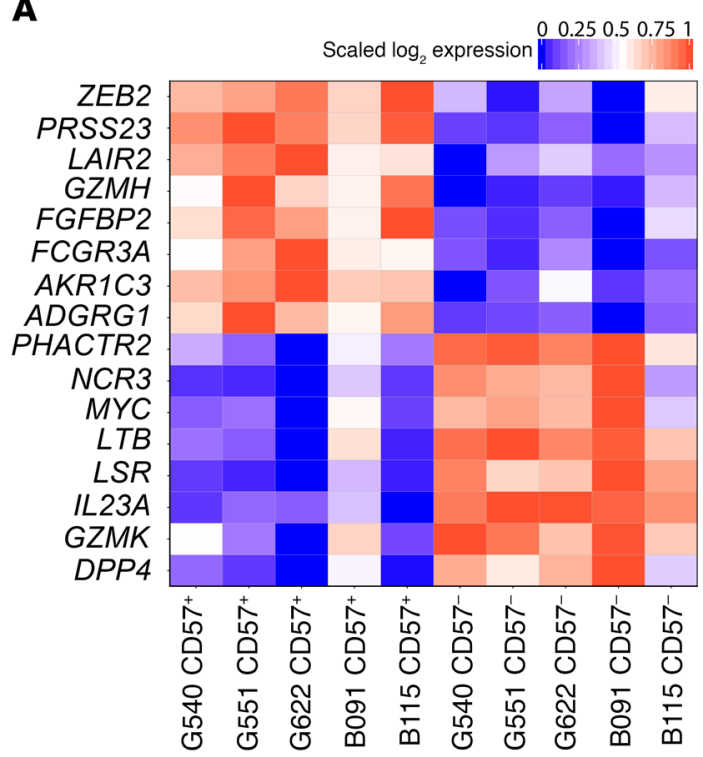

B

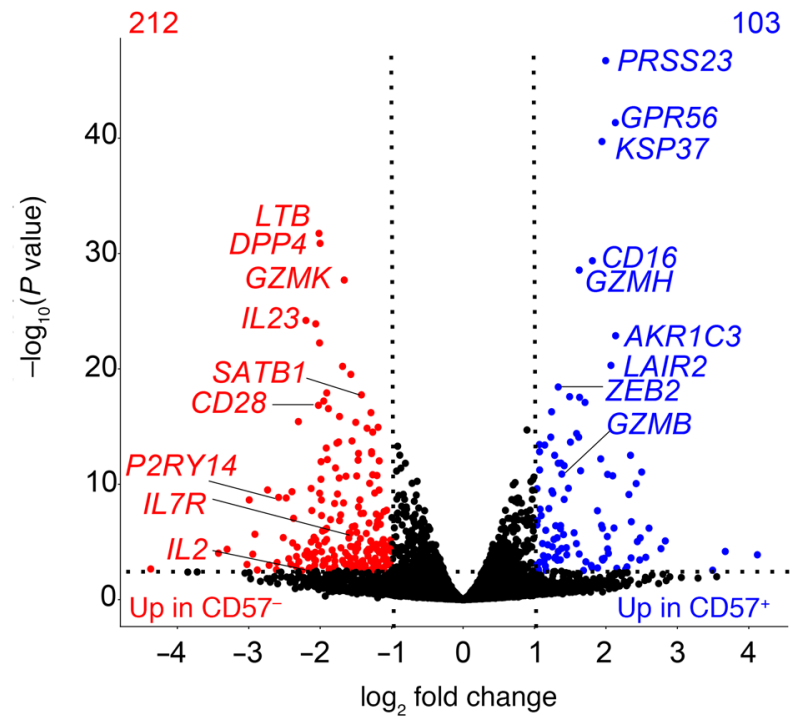

C

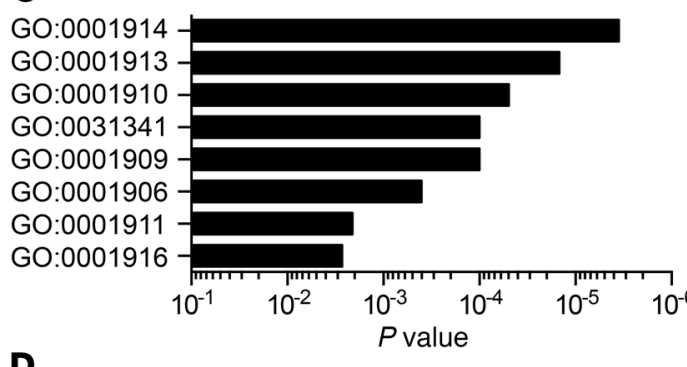

D

Regulation of T cell-mediated cytotoxicity

T cell-mediated cytotoxicity

Regulation of leukocyte-mediated cytotoxicity

Regulation of cell killing

Leukocyte-mediated cytotoxicity

Cell killing

Negative regulation of leukocyte-mediated cytotoxicity

Positive regulation of $\mathrm{T}$ cell-mediated cytotoxicity
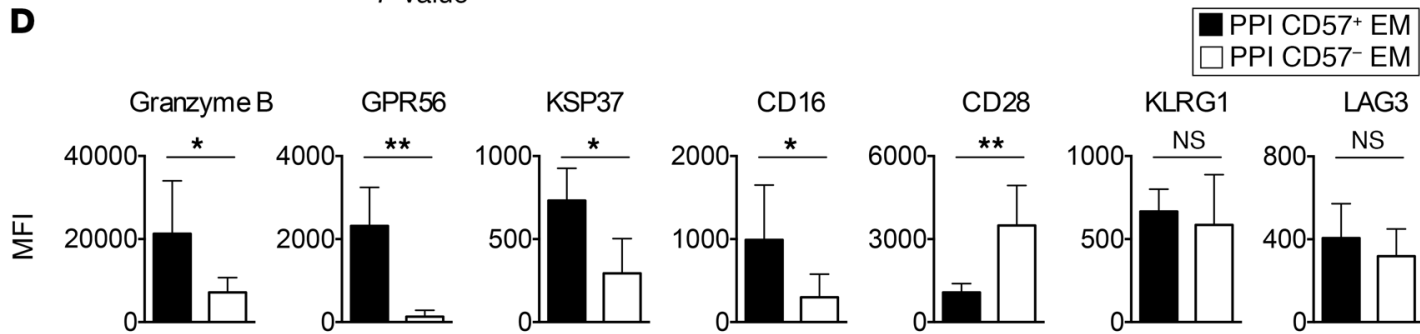

Figure 3. Gene and protein expression profiles indicate enhanced cytotoxic capability of $\mathrm{CD}^{2} 7^{+}$effector memory $\mathrm{CD} 8^{+} \mathrm{T}$ cells in type 1 diabetes patients. (A) RNA sequencing of $\mathrm{CD57} 7^{+}$and $\mathrm{CD} 57^{-}$effector memory CD8 $8^{+} \mathrm{T}$ cells. The top $5 \%$ differentially expressed genes are shown. (B) Volcano plot showing all genes upregulated (blue dots) and downregulated (red dots) in CD57+ compared with CD57- effector memory CD8 ${ }^{+} \mathrm{T}$ cells. Genes with Benjamini-Hochberg adjusted $P \leq 0.05$ and absolute $\log _{2}$ fold change greater than 1 were considered significant. Differential expression analysis was performed with the DESeq2 package in R. Horizontal dashed line, FDR $=0.05$; vertical dashed line, $\log _{2}$ (fold change) $=1$. (C) Significantly enriched gene ontology terms represented within differentially expressed genes. Gene ontology enrichment was performed using the R package clusterProfiler, and ontologies with adjusted $P \leq 0.05$ were considered significant. (D) Protein expression of key differentially expressed genes in PPI-specific CD57 ${ }^{+}$and $C D 57^{-}$effector memory CD8 ${ }^{+}$ T cells assessed by flow cytometry ( $n=5$ type 1 diabetes subjects). Bars and error bars represent means \pm SD. Mann-Whitney test, ${ }^{*} P<0.05,{ }^{* *} P<0.01$. $\mathrm{MFI}$, mean fluorescence intensity.

Effector memory cells circulate in the blood and contain high levels of cytolytic molecules in order to respond rapidly to virus infections or eradicate tumor cells via targeted destruction. The finding that the effector memory compartment of $\beta$ cell-specific $\mathrm{CD} 8^{+} \mathrm{T}$ cell populations correlates with $\mathrm{C}$-peptide changes indicates that this subset is important in driving disease. However, little is currently known about the dynamics and role of antigen-specific effector memory $\mathrm{CD} 8^{+} \mathrm{T}$ cells in type 1 diabetes pathology. Studies in nonobese diabetic mice have reported that $\mathrm{CD} 8^{+} \mathrm{T}$ cells specific for the islet antigen IGRP have an effector memory phenotype, which they acquire in the islets before emigrating to the periphery as stable effector memory cells $(30,31)$. Our study demonstrates a connection between $\beta$ cell function in the islets and levels of $\beta$ cell-specific $\mathrm{CD} 57^{+}$effector memory cells in the blood. Indeed, the network association modeling that we conducted indicates that immune changes are coordinated across multiple $\beta$ cell specificities in a manner that is unrelated to responses against viruses. These data strongly imply a dialogue between the $\beta$ cell and $C D 8^{+} \mathrm{T}$ cells. This could arise directly, as a result of cognate interactions between target and effector cells in the tissues that result in spillover of cyto- 
A

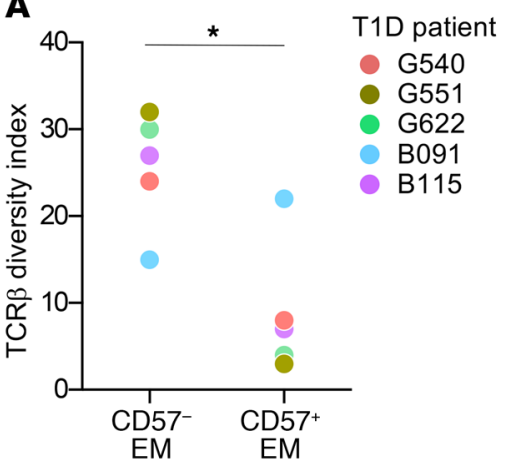

B

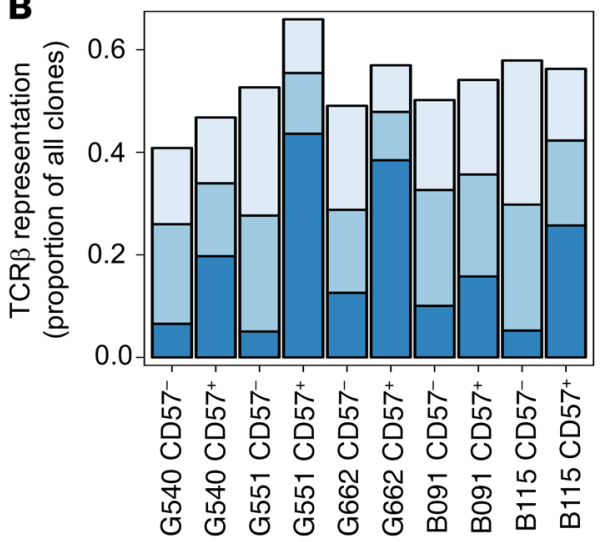

C

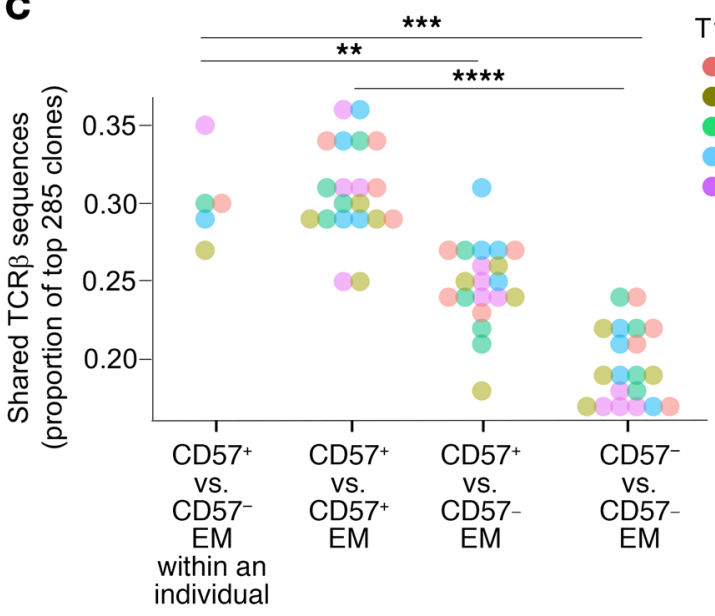

Clone size

$\square$ Small (0-0.001)

$\square$ Medium (0.001-0.01)

Large (0.01-1)
T1D patient

- G540

G551

- G622

B091

B115
Figure 4. Clonal TCR diversity and sharing are enhanced in $\mathrm{CD57}^{+}$effector memory $\mathrm{CD8}^{+} \mathrm{T}$ cells in type 1 diabetes patients. (A) TCR $\beta$ sequence diversity in $\mathrm{CD}^{+} 7^{+}$and $\mathrm{CD} 57^{-}$effector memory (EM) CD8 ${ }^{+} T$ cells. Wilcoxon test, ${ }^{*} P<0.05, n=5$. (B) Representation of TCR $\beta$ clones within $\mathrm{CD} 57^{+}$ and $\mathrm{CD}^{-} 7^{-} \mathrm{EM} \mathrm{CD8}{ }^{+} \mathrm{T}$ cell samples given as a proportion of the total number of clones. (C) TCR $\beta$ sequence sharing between $\mathrm{CD} 57^{+}$and $\mathrm{CD} 57^{-} \mathrm{EM}$ $\mathrm{CD}^{+} \mathrm{T}$ cells within a subject ("CD57+ vs. CD57- EM within an individual," $n=5$ ), between $C D 57^{+} \mathrm{EM}$ $\mathrm{CD8}{ }^{+} \mathrm{T}$ cells from different subjects ("CD57+ vs. $\mathrm{CD}^{+} 7^{+} \mathrm{EM}, " \mathrm{n}=20$ ), between $\mathrm{CD} 57^{+}$and $\mathrm{CD} 57^{-} \mathrm{EM}$ $\mathrm{CD8}{ }^{+} \mathrm{T}$ cells from different subjects ("CD57+ vs. CD57- EM," $n=20$ ), and between CD57+ EM CD8 ${ }^{+}$ T cells from different subjects ("CD57' vs. CD57 $E M, " n=20$ ). The top 285 represented clones in each sample were analyzed because the sample with the fewest clones had 285 clones. Wilcoxon test, ${ }^{* *} P<0.01,{ }^{* * *} P<0.001,{ }^{* * *} P<0.0001$. lytically differentiated $\mathrm{CD} 8^{+} \mathrm{T}$ cells into the blood. Alternatively, it could arise indirectly, following cross-presentation of $\beta$ cell autoantigens in secondary lymphoid organs resulting in cytotoxic $\mathrm{CD}^{+}$ $\mathrm{T}$ cells entering the circulation. In either case, the $\mathrm{CD} 57^{+}$effector memory $\mathrm{CD} 8^{+} \mathrm{T}$ cells that are generated have enhanced cytolytic function and are immediately available for recruitment from the blood into islets where insulin content remains high. Thus, the autoreactive $\mathrm{CD}^{+} \mathrm{T}$ cell response in type 1 diabetes describes a process of calibration (levels change) and tuning (differentiation status changes) that is characteristic of an adaptive immune response that is under the control of antigen. Our findings further emphasize how the disease may be tractable to an immunotherapy approach that limits the function of autoreactive activated $\mathrm{CD} 8^{+}$ $\mathrm{T}$ cells. Indeed, this rationale provided the basis for the successful use of alefacept, which preferentially engages memory $\mathrm{CD} 8^{+} \mathrm{T}$ cells, as an intervention in new-onset type 1 diabetes (32).

Unexpectedly, we also found that expansions in a small number of virus-specific memory $\mathrm{CD} 8^{+} \mathrm{T}$ cell subsets were associated with C-peptide loss. This finding contrasted with that for autoreactive $\mathrm{CD} 8^{+} \mathrm{T}$ cells in 2 respects: first, because a negative correlation between virus-specific $\mathrm{T}$ cell subsets and C-peptide was the more typical finding; and second, because the involvement of specific subsets of virus-specific $\mathrm{CD} 8^{+} \mathrm{T}$ cells was less clear, suggesting a more complex relationship. We observed considerable heterogeneity within the virus-specific $\mathrm{T}$ cell subsets associated with C-peptide change, probably reflecting diversity of immune responses to the viruses analyzed. In addition, within this data set, we were limited to knowing baseline serological status for CMV and EBV, and within-study use of influenza vaccine in a small number of cases. Thus we have no insight into wild-type exposures during the study, nor how to relate these to $\mathrm{CD} 8^{+} \mathrm{T}$ cell subsets. Divergent $\mathrm{CD} 8^{+} \mathrm{T}$ cell responses are elicited depending on whether the virus is cleared, as in the case of acute infection with influenza virus; whether it persists as a latent virus undergoing periodic reactivation, as with $\mathrm{EBV}$; or whether the virus induces a "smoldering" chronic infection characterized by pockets of ongoing viral replication, as is the case for CMV (33-35). Furthermore, epitopes from lytic or latent proteins within a virus can influence the $\mathrm{T}$ cell response; for example, latent $\mathrm{EBV}$ epitopes elicit a memory $\mathrm{CD} 8^{+} \mathrm{T}$ cell response, whereas lytic epitopes drive a more differentiated effector $\mathrm{T}$ cell phenotype (36). The potential role for viruses in type 1 diabetes development is controversial, has not previously been examined using this approach, and will clearly need closer inspection in future studies designed specifically to test viral hypotheses; but perhaps some initial conclusions can be drawn from our results. First, the data do not appear to support the role of a single virus, or a chronic infection, since this would be more likely to yield a virus- or subset-specific change similar to that observed for autoreactive $\mathrm{CD} 8^{+} \mathrm{T}$ cells. One interpretation is that antiviral responses have global influences on unrelated, contemporaneous autoimmune responses through bystander effects, and in this way contribute to islet pathology. Second, there is no 


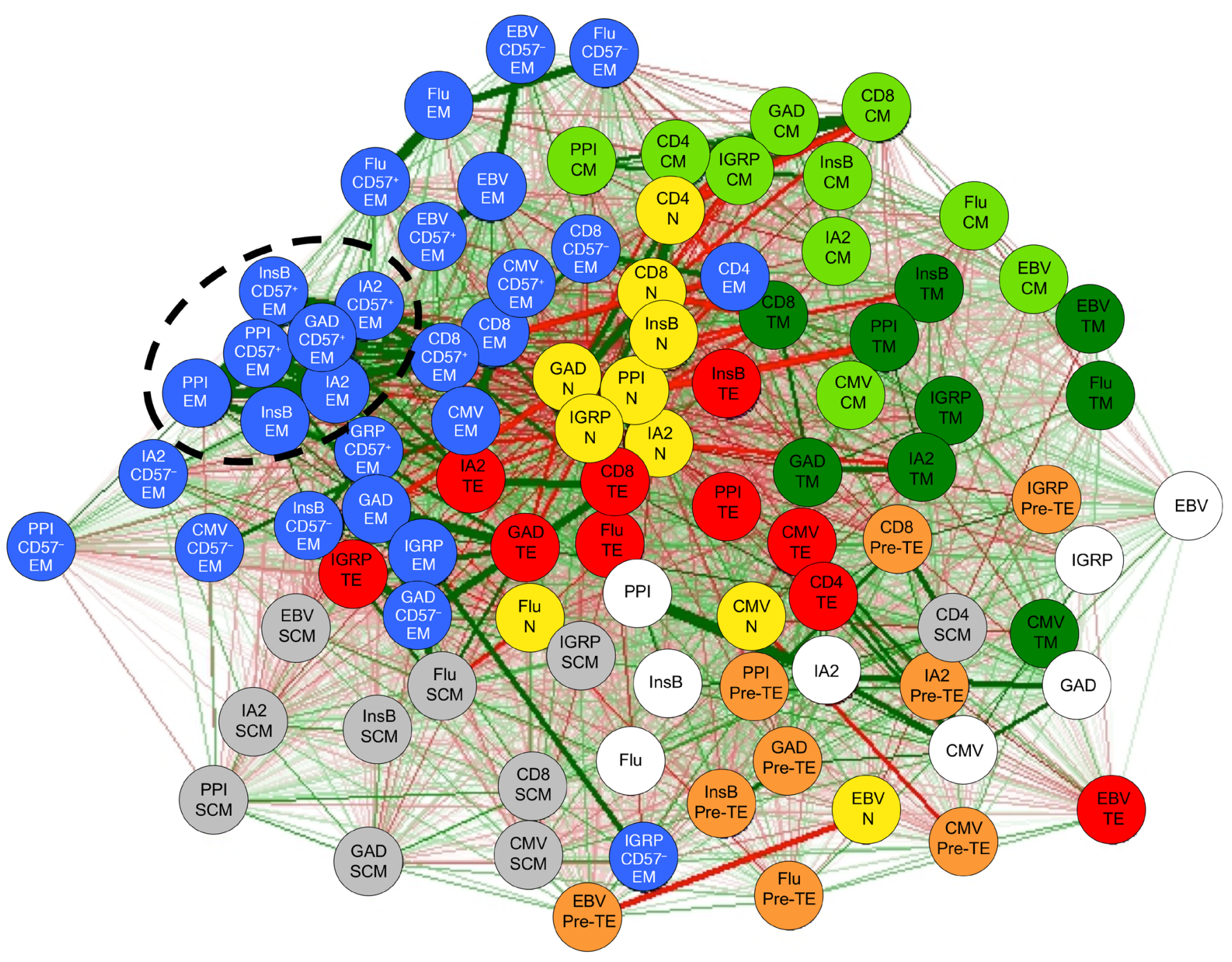

Figure 5. Visualization of the relationships between $\mathrm{CD8}^{+} \mathbf{T}$ cell subsets over time. Pairwise correlations between $\mathrm{CD} 8^{+} \mathrm{T}$ cell subsets are displayed in a "network association plot" in which each T cell subset is represented by a node and nodes are connected by lines whose width is proportional to the strength of the correlation. Green lines indicate positive correlations and red lines indicate negative correlations. Nodes are also clustered on the strength of their correlations. Each CD8 ${ }^{+} \mathrm{T}$ cell subset is colored uniquely: naive (N), yellow; stem cell memory (SCM), gray; central memory (CM), light green; transitional memory (TM), dark green; effector memory (EM)/CD57+ effector memory (CD57 EM)/CD57- effector memory (CD57- EM), blue; pre-terminal effector (pre-TE), orange; terminal effector (TE), red; total tetramer-positive $C D 8^{+} T$ cell populations, white. The dashed oval highlights strong correlations between $\beta$ cell-specific $C D 57^{+}$effector memory $C D 8^{+} T$ cell subsets.

clear support for a virus- $\beta$ cell cross-reactivity or mimicry process, since the network association modeling does not highlight any notable links between virus- and $\beta$ cell-specific immune subset changes. Thus, it seems more likely that if viruses impact upon $\beta$ cell loss, it relates to sporadic rather than continuous exposure (e.g., infection, immunization, or emergence of latent virus).

Notably, we found that relationships between autoreactive $\mathrm{CD}^{+} \mathrm{T}$ cells and C-peptide levels were considerably more pronounced in children below 12 years of age compared with older subjects, suggesting that distinct pathogenic mechanisms operate in this younger age group in the period after diagnosis. Indeed, considerable disease heterogeneity has been observed in type 1 diabetes patients based on their age at diagnosis. For example, children typically develop disease with more severe and rapid onset of symptoms and show a faster rate of C-peptide decline after diagnosis compared with adults (13). Furthermore, agerelated differences in islet infiltration have been described, with younger subjects showing a greater infiltration of immune cells, including $\mathrm{CD} 8^{+} \mathrm{T}$ cells as well as B lymphocytes (5). In addition, peripheral blood $\mathrm{CD} 4^{+} \mathrm{T}$ cell autoreactivity shows a greater target antigen breadth in children than in adults, and is especially focused on proinsulin, as appears to be the case for $\mathrm{CD}^{+} \mathrm{T}$ cell responses in the present study (37). Thus the accentuated relationships we observe between $\beta$ cells and $\mathrm{CD} 8^{+} \mathrm{T}$ cells in young children point to distinct underlying immunological pathways, with associated implications for immune monitoring and therapeutic approaches in this patient subgroup. It is tempting to speculate from these emerging studies that "classical" autoreactive, adaptive immune pathways (autoantibodies, autoreactive $\mathrm{CD} 4^{+}$and $\mathrm{CD} 8^{+} \mathrm{T}$ cells) have a greater influence over $\beta$ cell loss in younger patients, and 


\section{Table 5. Virus-specific $\mathrm{CD8}^{+} \mathrm{T}$ cell subset canonical correlation coefficients}

\begin{tabular}{|c|c|}
\hline Virus-specific CD8 ${ }^{+} \mathrm{T}$ cell population & Canonical coefficient \\
\hline CMV naive & 1.6631 \\
\hline CMV pre-terminal effector & 1.1043 \\
\hline Influenza $\mathrm{CD} 57^{+}$effector memory & 0.8071 \\
\hline CMV central memory & 0.5338 \\
\hline EBV SCM & 0.5031 \\
\hline CMV CD57+ effector memory & 0.4853 \\
\hline CMV terminal effector & 0.4773 \\
\hline Influenza terminal effector & 0.4252 \\
\hline CMV transitional memory & 0.3643 \\
\hline Influenza central memory & 0.3344 \\
\hline Influenza transitional memory & 0.3089 \\
\hline EBV terminal effector & 0.2437 \\
\hline EBV transitional memory & 0.2313 \\
\hline CMV SCM & 0.2093 \\
\hline Influenza naive & 0.1666 \\
\hline Influenza SCM & 0.1529 \\
\hline EBV naive & 0.126 \\
\hline EBV central memory & 0.0823 \\
\hline EBV CD57- effector memory & -0.106 \\
\hline EBV pre-terminal effector & -0.1649 \\
\hline EBV CD57+ effector memory & -0.294 \\
\hline Influenza pre-terminal effector & -0.3717 \\
\hline CMV CD57- effector memory & -0.4435 \\
\hline Influenza CD57- effector memory & -0.5162 \\
\hline
\end{tabular}

our study can be considered to be consistent with this. However, this hypothesis should undergo further examination, since the numbers of subjects we studied are limited once they are binned into specific age ranges, and our study was not designed or powered to specifically address this question.

Expression of $\mathrm{CD} 57$ on the surface of $\mathrm{CD} 8^{+} \mathrm{T}$ cells increases during $\mathrm{T}$ cell differentiation and is considered to be a marker of cytotoxic function $(26,38-44)$. CD57 is expressed by heterogeneous populations of memory $\mathrm{T}$ cells and terminally differentiated effector $\mathrm{T}$ cells $(45,46)$. In a previous study we observed that CD57 expression by $\beta$ cell-specific CD8 ${ }^{+} \mathrm{T}$ cells was increased in type 1 diabetes patients compared with healthy controls, implicating CD57 as a disease-associated marker (8). In the present study we pinpoint the critical CD57-expressing $\mathrm{T}$ cell subset that associates with $\beta$ cell function. We report that CD57 expression is an important distinguishing feature of a particular subgroup of $\beta$ cellspecific effector memory $\mathrm{T}$ cells, the dynamics of which correlate with C-peptide changes in type 1 diabetes.

$\mathrm{CD} 57$ is considered to be a marker of antigen experience, and is one of several markers commonly used to define senescent and exhausted $\mathrm{T}$ cell states, which arise from repetitive or excessive and continuous stimulation, respectively, and display weak proliferative capacity (47-49). However, it is known that cells expressing so-called "inhibitory" molecules such as CD57 can also exhibit higher cytotoxic activity and more pronounced cytokine production than cells of a less differentiated phenotype $(49,50)$. T cell exhaustion has been identified as a beneficial prognostic indicator in several autoimmune diseases, and, notably, in type 1 diabetes subjects accumulation of partially exhausted $\mathrm{CD} 8^{+} \mathrm{T}$ cells is associated with a favorable response to anti-CD3 treatment $(51,52)$. The CD57-expressing $\mathrm{CD} 8^{+} \mathrm{T}$ cell population is heterogeneous and is composed of various functionally different subsets (50). To our knowledge, this is the first study to examine the phenotype of $\mathrm{T}$ cells that display or lack CD57 expression within the effector memory $\mathrm{CD} 8^{+} \mathrm{T}$ cell compartment. Our data indicate that the CD57-expressing effector memory $\mathrm{CD} 8^{+} \mathrm{T}$ cell subset is associated with enhanced cytotoxicity rather than an exhausted phenotype. In comparison with their $\mathrm{CD} 57^{-}$counterparts, $\mathrm{CD} 57^{+}$effector memory $\mathrm{CD} 8^{+} \mathrm{T}$ cells did not show enhanced expression of genes associated with exhaustion in other studies, including KLRG1, LAG3, TIGIT, EOMES, CD160, PD-1, 4-1BB, CD244, CTLA4, PTGER2, LILRB4, CD160, CD86, NFAT, TIM3, TRAF1, IL1O, TGFB, IL6, and SMAD2 $(47,51,52)$. In contrast, $\mathrm{CD}^{2} 7^{+}$effector memory $\mathrm{CD} 8^{+} \mathrm{T}$ cells displayed higher levels of genes such as GZMB, GZMH, KSP37, and GPR56, indicating an active potential for cytotoxicity in this subset.

Interestingly, we observed that both $\mathrm{CD} 57^{+}$and $\mathrm{CD} 57^{-}$fractions of the total effector memory $\mathrm{CD} 8^{+} \mathrm{T}$ cell pool contained $\mathrm{T}$ cells bearing common TCR $\beta$ sequences, which suggests that highly differentiated $\mathrm{CD} 57^{+}$effector memory T cells may arise from the CD57- effector memory $\mathrm{T}$ cell pool. Indeed, TCR $\beta$ sharing has been described between $\mathrm{CD} 57^{+}$and $\mathrm{CD} 57^{-} \mathrm{CD} 8^{+} \mathrm{T}$ cells in healthy subjects (53). Furthermore, our RNA sequencing data indicate that the CD57- effector memory pool has properties of a self-renewing population of memory $\mathrm{T}$ cells expressing genes with the potential to replenish the cytolytically active $\mathrm{CD} 57^{+}$effector memory $\mathrm{T}$ cell compartment (54). Particular clonotypes were expanded within the total $\mathrm{CD} 7^{+}$effector memory $\mathrm{CD} 8^{+} \mathrm{T}$ cell fraction, and were highly shared between patients, hinting that effector memory $\mathrm{T}$ cells with particular specificities associated with disease may upregulate expression of CD57 in order to exert immediate effector functions and potentially contribute to $\beta$ cell destruction.

In summary, through longitudinal tracking of $\beta$ cell-reactive $\mathrm{CD}^{+} \mathrm{T}$ cell subsets in the blood alongside measurement of clinically meaningful $\beta$ cell function, we uncover a relationship that provides further support for a disease model in which the presence of $\beta$ cells is a driver of cytotoxic autoimmunity. Interestingly, this functionality seems to reside within a clearly definable subset of effector memory $\mathrm{CD}^{+} \mathrm{T}$ cells, the tracking of which in the blood using new technologies may assist in future development of useful surrogate markers of ongoing $\beta$ cell damage in the tis-

\section{Table 6. Total CD8+ $\mathrm{T}$ cell subset canonical correlation scores}

\begin{tabular}{|c|c|}
\hline Total CD8 $^{+} \mathrm{T}$ cell population & Canonical coefficient \\
\hline Central memory & 0.1909 \\
\hline Transitional memory & 0.1383 \\
\hline CD57- effector memory & 0.0873 \\
\hline SCM & 0.0631 \\
\hline Terminal effector & 0.0616 \\
\hline Pre-terminal effector & 0.0397 \\
\hline $\mathrm{CD} 7^{+}$effector memory & 0.0047 \\
\hline Naive & -0.2165 \\
\hline
\end{tabular}


$\beta$ Cell-specific T cell CCA
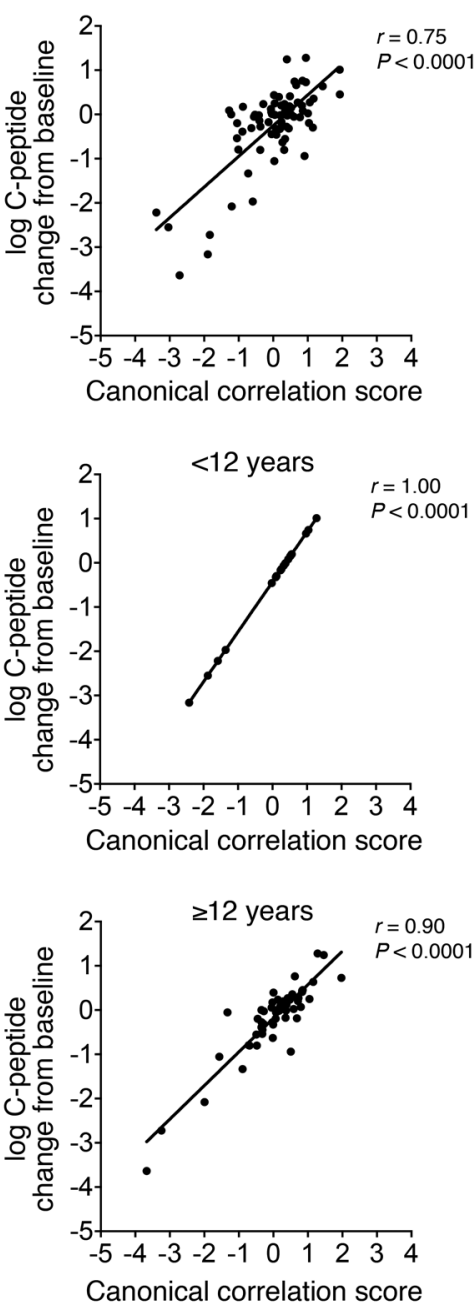

Virus-specific T cell CCA
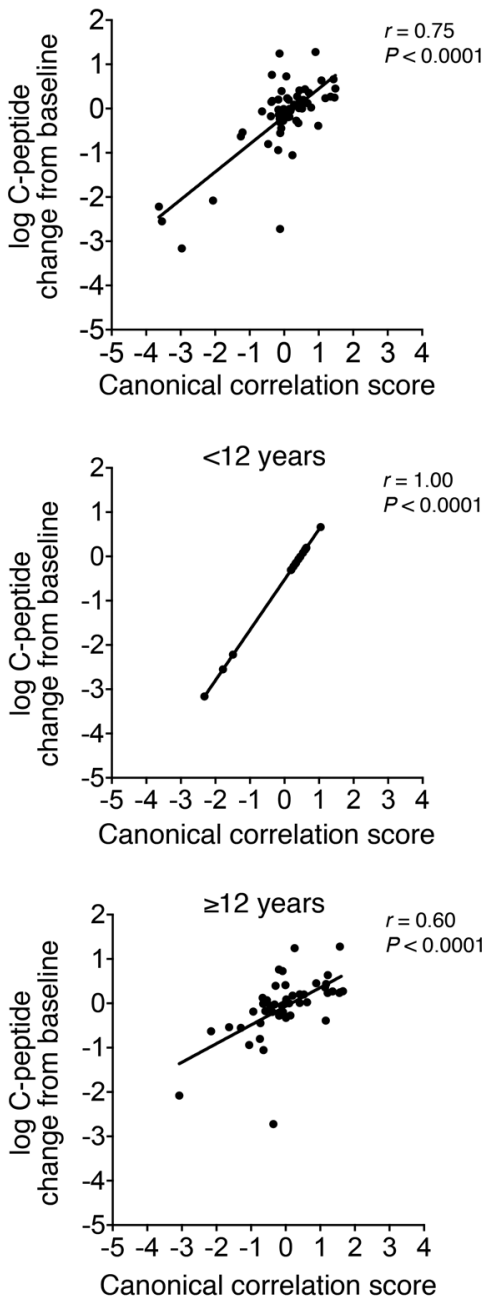

Total CD8 ${ }^{+}$T cell CCA
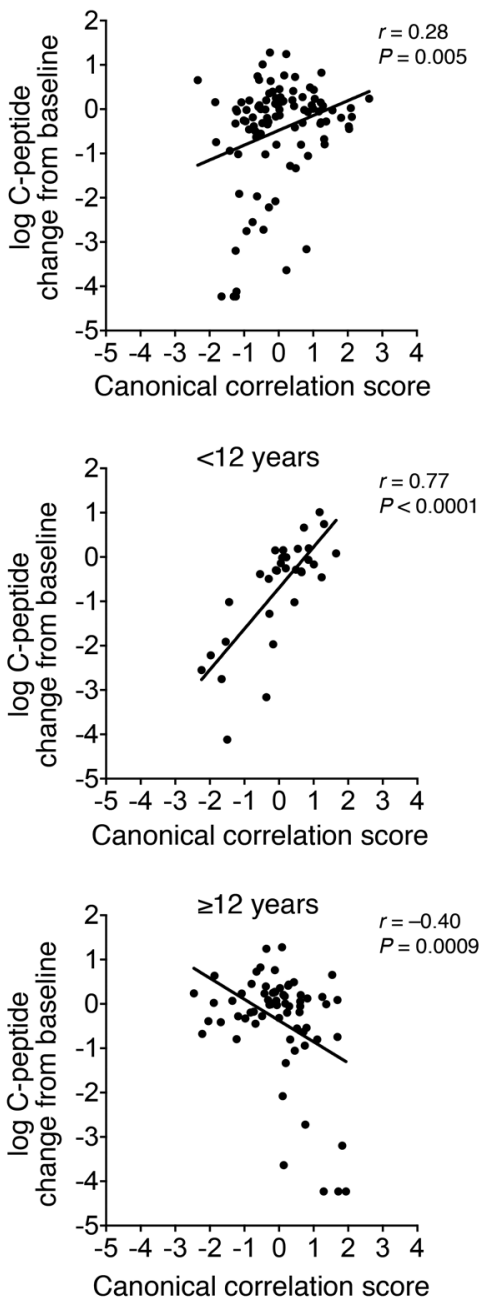

Figure 6. Canonical correlation analysis of $\mathrm{CD8}^{+} \mathbf{T}$ cell subsets and C-peptide. The canonical correlation score represents a combination of multiple $C D 8^{+} T$ cell subset frequencies. The canonical correlation score is plotted against the log C-peptide change from baseline for each subject at each visit. Data from $\beta$ cell-specific, virus-specific, or total CD8 ${ }^{+}$T cell data sets were used for separate canonical correlation analyses (CCAs). The correlation between the canonical correlation score and log C-peptide change from baseline was determined after adjustment for repeated measures. All subjects, $n=38 ;$ subjects $<12$ years old, $n=15$; subjects $\geq 12$ years old, $n=23$.

sues; and the targeting of which could be a promising strategy for arresting disease progression.

\section{Methods}

Subjects. Archived PBMC samples were obtained from 38 type 1 diabetes patients who were enrolled in the placebo arms of 3 TrialNet studies (clinical trial registration numbers NCT00529399, NCT00505375, NCT00947427; for details see www.diabetestrialnet. org). Demographic and baseline characteristics are reported in Supplemental Tables 1 and 2. Entry requirement for all studies included a requirement for peak stimulated C-peptide by mixed meal tolerance test (MMTT) of $\geq 0.2 \mathrm{pmol} / \mathrm{ml}$, positivity for at least 1 diabetes autoantibody, and type 1 diabetes diagnosis within 100 days of randomization. The age range spanned 6-34 years. Subjects were monitored for up to 2 years after randomization with regularly scheduled MMTTs to ensure tight glycemic control. Antibodies against CMV and EBV were assessed at screening. At months 2-11 inclusive, some subjects received annual clinically indicated killed influenza vaccine at the appropriate time of the year. Response to immunization was determined through analysis of pre-dose and 4 -weeks ( \pm 7 days) post-dose samples (Supplemental Figure 3). We analyzed PBMCs taken at baseline and $6,12,18$, and 24 months after baseline visit. Individual trajectories of 2-hour C-peptide area under the curve (AUC) over 2 years are shown in Supplemental Figure 3. All longitudinal PBMC samples obtained per patient were assayed on the same day in a single experiment by an operator blinded to clinical data.

For RNA sequencing experiments, blood samples were taken from 5 HLA-A ${ }^{*} 24$-positive males (mean age 29 years \pm SD 5.5) with newly diagnosed type 1 diabetes (mean disease duration 8 months \pm $\mathrm{SD} 4.6$ ). For experiments for phenotyping of $\mathrm{CD} 57^{+}$and $\mathrm{CD} 57^{-}$effector memory $\mathrm{T}$ cells by flow cytometry, blood samples were taken from 10 HLA-A ${ }^{*} 02$-positive subjects ( $56 \%$ female, mean age 31 years \pm SD 5.9 ) with newly diagnosed type 1 diabetes (mean disease duration 2.5 months \pm SD 1.7).

Measuring $\beta$ cell function by MMTT. As per the TrialNet protocols, subjects underwent a 2-hour MMTT. Tests were started before $10 \mathrm{am}$, 
fasting glucose was required to be $70-200 \mathrm{mg} / \mathrm{dl}$, and long-acting insulin was permitted but no short-acting insulin (including no pump bolus) was allowed within 2 hours before start of test. A standard preparation of fat, carbohydrate, and protein (Boost-HP, Nestle Health Care Nutrition Inc.) was used at a dose of $6 \mathrm{mg} / \mathrm{kg}$ to a maximum of $360 \mathrm{ml}$. Two-hour C-peptide AUC was calculated using the trapezoidal method over the initial 120-minute time period. Areas were then divided by 120 minutes for statistical analysis.

Tetramer assembly. Soluble, fluorochrome-conjugated peptideMHC class I tetramers were generated as described previously (55) to produce pHLA-A $\mathrm{O}^{*}$ and $\mathrm{pHLA}-\mathrm{A}^{\star} 24$ tetramers. Tetramers were assembled over 5 separate 20 -minute steps with the successive addition of streptavidin-APC (Life Technologies) to monomeric pHLA at a molar streptavidin/pHLA ratio of 1:4. PBS was added to give a final multimer concentration of $0.1 \mathrm{mg} / \mathrm{ml}$ pHLA content. Tetramers were stored in the dark at $4^{\circ} \mathrm{C}$ and used on the same day as assembly. The peptide epitopes incorporated into the tetramers are summarized in Table 1.

Cell staining and flow cytometry. PBMCs were thawed in a $37^{\circ} \mathrm{C}$ water bath until a pea-sized pellet of ice remained. Once completely thawed, cells were transferred from the cryovial to a 30-ml tube. Nine milliliters of $37^{\circ} \mathrm{C}$ thaw media (RPMI 1640 supplemented with $10 \%$ human serum) was added drop-wise to the cells while the tube was gently shaken. The cryovial was rinsed out with $1 \mathrm{ml}$ thaw media and added drop-wise to the tube. Cells were centrifuged at $200 \mathrm{~g}$ for 8 minutes. The supernatant was discarded, the cell pellet was resuspended in $10 \mathrm{ml}$ room-temperature defrost media, and cells were counted. Cells were centrifuged at $400 \mathrm{~g}$ for 4 minutes and were transferred to flow cytometry tubes, washed with PBS, and stained with LIVE/DEAD Aqua amine-reactive dye (Invitrogen) for 10 minutes at room temperature, followed by washing with PBS. PBMCs were incubated with the protein kinase inhibitor dasatinib (Axon Medchem) at a final concentration of $50 \mathrm{nM}$ for $30 \mathrm{~min}$ utes at $37^{\circ} \mathrm{C}$ to enhance the detection of low-avidity $\mathrm{T}$ cells $(8,56)$ and CCR7 BV421 monoclonal antibody (clone G043H7, BioLegend). Subsequently, PBMCs were stained for 10 minutes at $37^{\circ} \mathrm{C}$ with $1 \mu \mathrm{g}$ of pHLA tetramer per tube. After washing with FACS buffer (PBS supplemented with $2 \%$ human $\mathrm{AB}$ serum and $3 \% \mathrm{FCS}$ ), PBMCs were stained with mouse anti-APC unconjugated monoclonal antibody (clone PE001, BioLegend) at a concentration of $10 \mathrm{mg} / \mathrm{ml}$ on ice for 20 minutes to stabilize binding of APC-labeled tetramers (57). After washing with FACS buffer, cells were stained with the following surface monoclonal antibodies/fluorophores for 20 minutes on ice: CD3 BV785, CD8 PECy7, CD27 BV605 (clones OKT3, SKI, O323, respectively, all BioLegend); CD14 V500, CD16 V500, CD19 V500, CD45RA PE-CF594, CD95 PE, CD57 FITC (clones M5E2, 3G8, HIB19, HI100, DX2, NK-1, respectively, all BD Biosciences); CD4 PECy5.5 (clone S3.5, Invitrogen). Stained PBMCs were kept on ice and in the dark until acquisition on the same day on an LSRFortessa cell analyzer (BD Biosciences). The median percentage recovery of PBMCs from frozen samples was $98 \%$, and the median viability was $100 \%$. Gates to define tetramer positivity were set based on PBMC samples that were not stained with tetramer. No $\mathrm{CD}^{+} \mathrm{T}$ cells were stained in the absence of tetramers. Within the antigenspecific $\mathrm{CD}^{+} \mathrm{T}$ cell populations and within the total $\mathrm{CD} 8^{+} \mathrm{T}$ cell populations, $9 \mathrm{CD}^{+} \mathrm{T}$ cell subsets were assessed for analysis using the following cell surface marker combinations: naive $\left(\mathrm{N} ; \mathrm{CCR}^{+} \mathrm{CD} 45 \mathrm{RA}^{+} \mathrm{CD} 27^{+} \mathrm{CD} 57\right.$ $\mathrm{CD}^{-} 5^{-}$), stem cell memory-like (SCM; $\mathrm{CCR}^{+} \mathrm{CD} 45 \mathrm{RA}^{+} \mathrm{CD} 27^{+} \mathrm{CD} 57$ $\left.\mathrm{CD} 95^{+}\right)$, central memory $\left(\mathrm{CM} ; \mathrm{CCR} 7^{+} \mathrm{CD} 45 \mathrm{RA}^{-} \mathrm{CD} 27^{+}\right)$, transitional memory (TM; CCR7-CD45RA-CD27 ${ }^{+}$), effector memory (EM; CCR7$\left.\mathrm{CD}^{2} 5 \mathrm{RA}^{-} \mathrm{CD}^{2} 7^{-}\right)$, effector memory populations defined by presence or absence of the activation marker CD57 (CD57 $\left.{ }^{+} \mathrm{EM} / \mathrm{CD} 57^{-} \mathrm{EM}\right)$, preterminal effector (pre-TE; CCR7-CD45RA ${ }^{+} \mathrm{CD} 27^{+}$), and terminal effector (TE; CCR7 ${ }^{-} \mathrm{CD} 45 \mathrm{RA}^{+} \mathrm{CD} 27^{-}$). The gating strategy is illustrated in Supplemental Figure 4. Flow cytometry data were analyzed using FlowJo version 9.4 (Tree Star). To maximize capture of phenotypic data, each stain used $3 \times 10^{6}$ to $4 \times 10^{6}$ (HLA-A ${ }^{*} 0201$ multimers) or $6 \times 10^{6}$ to $8 \times$ $10^{6}$ PBMCs (HLA-A 2402 multimers), which is in excess of the number typically used for phenotyping of $\beta$ cell-specific memory $\mathrm{CD}^{+} \mathrm{T}$ cells from ex vivo PBMC samples from type 1 diabetes patients $(8,58-60)$. A minimum of $1 \times 10^{4}$ live $\mathrm{CD} 8^{+} \mathrm{T}$ cells were collected for multimer analysis. Samples containing fewer than $1 \times 10^{4}$ live CD8 $8^{+} \mathrm{T}$ cells were excluded from the analysis. The mean number of live $\mathrm{CD}^{+} \mathrm{T}$ cells analyzed was $5.4 \times 10^{4}\left(\mathrm{SD} 8.9 \times 10^{4}\right)$, and the mean number of tetramerpositive $\mathrm{CD}^{+} \mathrm{T}$ cells per sample was 90 (SD 108).

In experiments for phenotyping $\mathrm{CD}^{+} 7^{+}$and $\mathrm{CD}^{-} 7^{-}$effector memory $\mathrm{T}$ cells by flow cytometry, thawed PBMCs were incubated with LIVE/DEAD Aqua amine-reactive dye, dasatinib, CCR7 antibody, pHLA, and surface monoclonal antibodies/fluorophores as described above, with the exception that staining with CD95 PE was omitted. Instead PBMCs were stained with the surface monoclonal antibodies GPR56 PE, KLRG1 PE, and CD16 PE, and the intracellular antibodies granzyme B PE, KSP37 PE, and LAG3 PE (clones CG4, 14C2A0, 3G8, QA16A02, TDA3, and 11C3C65, respectively, all BioLegend). Staining with CD16 V500 was omitted when CD16 PE antibody was used. Intracellular staining was performed by fixing cells in Fixation Buffer (BioLegend) and washing cells with Intracellular Staining Perm Wash Buffer (BioLegend) according to the manufacturer's instructions.

$C D 8^{+} T$ cell sorting for RNA sequencing. PBMCs were isolated on density gradients using Lymphoprep (Nycomed) and washed in RPMI supplemented with $2 \%$ human $A B$ serum. PBMCs were washed and stained as above, and $\mathrm{CD} 57^{+}$and $\mathrm{CD}^{-} 7^{-}$effector memory $\mathrm{CD} 8^{+} \mathrm{T}$ cells (gated as live $\mathrm{CD}^{-} 4^{-\mathrm{CD}} 16^{-} \mathrm{CD} 19^{-} \mathrm{CD} 4^{-}{ }^{-} \mathrm{CD} 3^{+} \mathrm{CD} 8^{+} \mathrm{CCR} 7^{-} \mathrm{CD} 45 \mathrm{RA}^{-}$ $\mathrm{CD}^{-} 7^{-}$) were sorted using a FACSAria (BD Biosciences) into BSA supplemented with $10 \% \mathrm{BSA} / 5$ mM EDTA.

RNA sequencing and data analysis. RNA was isolated immediately from cell pellets using the PicoPure RNA extraction kit (Thermo Fisher Scientific). cDNA was generated and amplified using the SMARTseq 4 Ultra Low Input RNA Kit (Clontech) on the contactless Labcyte liquid handling system (Labcyte Inc.). Two hundred nanograms of amplified cDNA was used from each sample where possible to generate libraries using the Ovation Ultralow Library System V2 kit (NuGEN). In brief, cDNA was fragmented through sonication on Covaris E220 (Covaris Inc.), repaired, and polished followed by ligation of indexed adapters. Adapter-ligated cDNA was pooled before final amplification to add flow cell primers. Libraries were sequenced on HiSeq 2500 (Illumina Cambridge) for 100 paired-end cycles in rapid mode.

Prealignment quality control for each sample, independently for forward and reverse reads, was performed using the stand-alone tool FastQC (BaseSpace Labs). Reads were trimmed using Trimmomatic (GenePattern) removing Illumina adapters and dropping reads shorter than 50 bases long. Reads were aligned to the reference genome (hg19) using HISAT2. PCR duplicates were removed using the MarkDuplicates function in Picard Tools (The Broad Institute). Counts were generated using HTSeq using human hg19 RefSeq from the University of California, Santa Cruz. Before differential gene expression analysis, 
genes with very low expression were discarded. Only genes with at least one count per million (before normalization) in at least 2 samples were used for downstream analysis in $\mathrm{R}$ and Bioconductor (61). Raw counts were normalized using the trimmed mean of $M$ values normalization method. Differential expression analysis was performed with the DESeq2 package in R. The test statistics' $P$ values were adjusted for multiple testing using the procedure of Benjamini and Hochberg. Genes with adjusted $P \leq 0.05$ and absolute $\log _{2}$ fold change greater than 1 were considered significant. Gene ontology enrichment was performed using the R package clusterProfiler, and ontologies with adjusted $P \leq$ 0.05 were considered significant. TCRB sequences were extracted from RNA-Seq FASTQ reads with MiXCR (MiLaboratory) with settings recommended for RNA-Seq. RNA-Seq data are deposited at https:// www.ebi.ac.uk/arrayexpress/ (accession number E-MTAB-6727).

Statistics. Analyses were conducted with statistical software R, SAS version 9.4 (SAS Institute), and/or GraphPad Prism.

Mixed-effects general linear model. The current study was a rigorously designed prospective analysis in which sample size was predetermined and the $\mathrm{T}$ cell populations to be studied were prespecified. The statistical methodology and modeling used were developed and previously used for the analysis of the relationship between $\mathrm{T}$ cell subsets and therapeutic effects of abatacept monotherapy in a clinical trial conducted by TrialNet (62). Sample size determinations for the present analysis were based on data collected in the abatacept study. Relationships between $\mathrm{T}$ cell and $\mathrm{C}$-peptide changes from baseline across time were analyzed with mixed-effects general linear models. T cell change from baseline at each visit was analyzed as the arithmetic change in T cell frequency from baseline. C-peptide change from baseline at each visit was analyzed as the natural $\log$ of the ratio of $\mathrm{C}$-peptide value to baseline value. Parameter estimates from the mixed-effects general linear model were used to estimate the log change in C-peptide change from baseline per unit increase in T cell populations (i.e., the "slope"). This is not relevant to the individual subject, but to the "average" subject, and is in keeping with the definition of "regression." Time in study (measured as months since baseline) was included in the model, and a variance components error structure was assumed for the repeated measures across time. Hence, estimates and $P$ values of the relationship between $\mathrm{T}$ cell and C-peptide ("slope") have been adjusted for the effects of time and within-subject correlation. In addition, the model was also adjusted for subject age and baseline $\mathrm{T}$ cell population. Associations between changes in T cell subsets and C-peptide were considered significant at $P$ $<0.05$. To aid interpretation of the results, $P$ values were also adjusted for multiple testing using the Benjamini-Hochberg method with a false discovery rate of $10 \%$. Additionally, the model was used to evaluate the relationships between $\mathrm{T}$ cell population and C-peptide changes when subjects were divided into 3 age groups $(<12$ years, $12-17$ years, $>17$ years). Although the youngest age group served as the referent, we report age-specific slopes and $P$ values estimated from the fitted model.

Network association plot. Pairwise Pearson correlations and $P$ values between $T$ cell populations were computed after adjusting out correlation induced by time and within-subject correlation by correlating residuals from a repeated-measures model. These correlations were displayed in a "network association plot," in which each T cell population is represented as a node and nodes are connected by lines whose width is proportional to the strength of the correlation. Further, our plot used "forced direction" to create a "spring plot," in which nodes are also clustered on the strength of their correlations.
Canonical correlation analysis. Canonical correlation analysis (CCA) was used to determine a combination of $\mathrm{T}$ cell subset frequencies most strongly correlated with log C-peptide change from baseline. CCA is similar to principal components analysis (PCA) in that they both reduce the dimensionality of the data to a smaller number of independent components. However, whereas the components determined in PCA are meant to explain the greatest amount of variation in the data, the components in CCA are meant to have the greatest correlation with a predicted variable (e.g., C-peptide). Thus, the CCA for $\mathrm{CD}^{+} \mathrm{T}$ cell subsets is a weighted combination of the subsets in which the weights have been selected to maximize the correlation of this new measurement with C-peptide change. In brief, CCA found a linear combination of variables (in this case, $\mathrm{CD} 8^{+} \mathrm{T}$ cell subset frequencies) that had the strongest correlation with an outcome variable (in this case, the log change in C-peptide from baseline) (63). CCA produced numerical coefficients for each of the variables ( $C D 8^{+} \mathrm{T}$ cell subsets). Then, for each subject in the study, a new variable was formed (typically referred to as a "score") by multiplying each of the $\mathrm{CD} 8^{+} \mathrm{T}$ cell subset frequencies by the corresponding numerical coefficient and summing these products. Thus, the new variable is a combination of multiple $\mathrm{CD}^{+} \mathrm{T}$ cell subset frequencies, referred to as a "canonical correlation score." Correlation and $P$ values were adjusted for withinsubject correlation arising from repeated measures.

TCR $\beta$ sequence analysis. For TCR $\beta$ sequence analysis, true diversity index was calculated using the tcR package. Sharing among TCR repertoires was quantified by calculation of the overlap coefficient [overlap $(X, Y)=\mid X$ and $Y \mid / \min (|X|,|Y|)$ ] for nucleotide sequences (species $=$ nucleotide sequence). All statistical analyses were conducted with SAS version 9.2 (SAS Institute) and R.

Study approval. All aspects of the study were approved by the South London Research Ethics Committee 5 (London, United Kingdom), REC reference 08/H0805/14, and the protocol and consent documents were approved by appropriate Independent Ethics Committees or Institutional Review Boards for participating TrialNet centers. All subjects or their parents gave written informed consent and assent as appropriate before study participation.

\section{Author contributions}

LY, AW, SS, AL, ME, IPA, RM, and CAB performed the experiments, evaluated data, and applied statistical analysis. GMD, KT, SH, A Skowera, and AKS contributed to tetramer assembly and staining and flow cytometry experiments. EF and A Saxena contributed to RNA library preparation and sequencing. LY wrote the manuscript. MP conceived and directed the project. All the authors had the opportunity to discuss the results and comment on the manuscript.

\section{Acknowledgments}

This work was supported by the UK Department of Health via the National Institute for Health Research Biomedical Research Centre Award to Guy's and St Thomas' National Health Service Foundation Trust in partnership with King's College London and the Juvenile Diabetes Research Foundation (JDRF) award "Immunological markers of beta cell decline in new onset type 1 diabetes" (17-2013583). We are grateful to Teo Staeva and Simi Ahmed for their advice on the project. Support is also acknowledged from the Innovative Medicines Initiative-2 Joint Undertaking under grant agreement 
115797 INNODIA, which receives support from the European Union's Horizon 2020 Research and Innovation Programme, and the European Federation of Pharmaceutical Industries and Associations, JDRF International, and the Leona M. and Harry B. Helmsley Charitable Trust to MP. TrialNet samples and metadata were obtained with permission through an ancillary study to the Type 1 Diabetes TrialNet Study. The Type 1 Diabetes TrialNet Study is a clinical trials network currently funded by the NIH through the National Institute of Diabetes and Digestive and Kidney Diseases, the National Institute of Allergy and Infectious Diseases, and the Eunice Kennedy Shriver National Institute of Child Health and Human Development; through the cooperative agreements U01 DK061010, U01 DK061034, U01 DK061042, U01 DK061058, U01 DK085461, U01 DK085465, U01 DK085466, U01 DK085476,
U01 DK085499, U01 DK085509, U01 DK103180, U01 DK103153, U01 DK103266, U01 DK103282, U01 DK106984, U01 DK106994, U01 DK107013, U01 DK107014, and UC4 DK106993; and through JDRF International. The contents of this article are solely the responsibility of the authors and do not necessarily represent the official views of the NIH or the JDRF. IPA is in receipt of a Marie Skłodowska-Curie Individual Fellowship (IF-EF), and AKS is a Wellcome Senior Investigator (WT100327MA).

Address for correspondence: Mark Peakman, Peter Gorer Department of Immunobiology, King's College London Faculty of Life Sciences and Medicine, 2nd Floor, Borough Wing, Guy's Hospital, London SE1 9RT, United Kingdom. Phone: 44.207.848.9605; Email:mark.peakman@kcl.ac.uk.
1. Roep BO, Peakman M. Antigen targets of type 1 diabetes autoimmunity. Cold Spring Harb Perspect Med. 2012;2(4):a007781.

2. Roep BO, Peakman M. Diabetogenic T lymphocytes in human type 1 diabetes. Curr Opin Immunol. 2011;23(6):746-753.

3. Coppieters KT, et al. Demonstration of isletautoreactive CD8 T cells in insulitic lesions from recent onset and long-term type 1 diabetes patients. JExp Med. 2012;209(1):51-60.

4. Willcox A, Richardson SJ, Bone AJ, Foulis AK, Morgan NG. Analysis of islet inflammation in human type 1 diabetes. Clin Exp Immunol. 2009;155(2):173-181.

5. Arif S, et al. Blood and islet phenotypes indicate immunological heterogeneity in type 1 diabetes. Diabetes. 2014;63(11):3835-3845.

6. Pinkse GG, et al. Autoreactive CD8 T cells associated with beta cell destruction in type 1 diabetes. Proc Natl Acad Sci U S A. 2005;102(51):18425-18430.

7. Babon JA, et al. Analysis of self-antigen specificity of islet-infiltrating $\mathrm{T}$ cells from human donors with type 1 diabetes. Nat Med. 2016;22(12):1482-1487.

8. Skowera A, et al. $\beta$-Cell-specific CD8 T cell phenotype in type 1 diabetes reflects chronic autoantigen exposure. Diabetes. 2015;64(3):916-925.

9. Skowera A, et al. CTLs are targeted to kill beta cells in patients with type 1 diabetes through recognition of a glucose-regulated preproinsulin epitope. J Clin Invest. 2008;118(10):3390-3402.

10. Knight RR, et al. A distinct immunogenic region of glutamic acid decarboxylase 65 is naturally processed and presented by human islet cells to cytotoxic CD8 T cells. Clin Exp Immunol. 2015;179(1):100-107.

11. Kronenberg D, et al. Circulating preproinsulin signal peptide-specific CD8 T cells restricted by the susceptibility molecule HLA-A24 are expanded at onset of type 1 diabetes and kill $\beta$-cells. Diabetes. 2012;61(7):1752-1759.

12. Knight RR, et al. Human $\beta$-cell killing by autoreactive preproinsulin-specific CD8 T cells is predominantly granule-mediated with the potency dependent upon T-cell receptor avidity. Diabetes. 2013;62(1):205-213.

13. Greenbaum CJ, et al. Fall in C-peptide during first 2 years from diagnosis: evidence of at least two distinct phases from composite
Type 1 Diabetes TrialNet data. Diabetes. 2012;61(8):2066-2073.

14. Morgan NG, Leete P, Foulis AK, Richardson SJ. Islet inflammation in human type 1 diabetes mellitus. IUBMB Life. 2014;66(11):723-734.

15. Keenan HA, et al. Residual insulin production and pancreatic $\beta$-cell turnover after 50 years of diabetes: Joslin Medalist Study. Diabetes. 2010;59(11):2846-2853.

16. Atkinson MA, Gianani R. The pancreas in human type 1 diabetes: providing new answers to ageold questions. Curr Opin Endocrinol Diabetes Obes. 2009;16(4):279-285.

17. Ogawa K, et al. A novel serum protein that is selectively produced by cytotoxic lymphocytes. JImmunol. 2001;166(10):6404-6412.

18. Peng YM, et al. Specific expression of GPR56 by human cytotoxic lymphocytes. J Leukoc Biol. 2011;90(4):735-740.

19. Björkström NK, et al. Elevated numbers of Fc gamma RIIIA ${ }^{+}\left(\mathrm{CD} 16^{+}\right)$effector CD8 T cells with NK cell-like function in chronic hepatitis $C$ virus infection. JImmunol. 2008;181(6):4219-4228.

20. Clémenceau B, et al. Effector memory alphabeta T lymphocytes can express Fc $\gamma$ RIIIa and mediate antibody-dependent cellular cytotoxicity. Jimmunol. 2008;180(8):5327-5334.

21. Andrade F, Fellows E, Jenne DE, Rosen A, Young CS. Granzyme $\mathrm{H}$ destroys the function of critical adenoviral proteins required for viral DNA replication and granzyme $B$ inhibition. EMBO J. 2007;26(8):2148-2157.

22. Afonina IS, Cullen SP, Martin SJ. Cytotoxic and non-cytotoxic roles of the CTL/NK protease granzyme B. Immunol Rev. 2010;235(1):105-116.

23. Wlodarski MW, et al. Phenotypic differences between healthy effector CTL and leukemic LGL cells support the notion of antigen-triggered clonal transformation in T-LGL leukemia. JLeukoc Biol. 2008;83(3):589-601.

24. Ramakrishna V, Sundarapandiyan K, Zhao B, Bylesjo M, Marsh HC, Keler T. Characterization of the human $\mathrm{T}$ cell response to in vitro CD27 costimulation with varlilumab. J Immunother Cancer. 2015;3:37.

25. Kaech SM, Tan JT, Wherry EJ, Konieczny BT, Surh CD, Ahmed R. Selective expression of the interleukin 7 receptor identifies effector CD8 T cells that give rise to long-lived memory cells.
Nat Immunol. 2003;4(12):1191-1198.

26. Hamann D, et al. Phenotypic and functional separation of memory and effector human CD ${ }^{+}$ T cells. J Exp Med. 1997;186(9):1407-1418.

27. Arosa FA. CD $8^{+} \mathrm{CD} 28^{-} \mathrm{T}$ cells: certainties and uncertainties of a prevalent human T-cell subset. Immunol Cell Biol. 2002;80(1):1-13.

28. Sallusto F, Lenig D, Förster R, Lipp M, Lanzavecchia A. Two subsets of memory T lymphocytes with distinct homing potentials and effector functions. Nature. 1999;401(6754):708-712

29. Omilusik KD, et al. Transcriptional repressor ZEB2 promotes terminal differentiation of $\mathrm{CD}^{+}$effector and memory $\mathrm{T}$ cell populations during infection. J Exp Med. 2015;212(12):2027-2039.

30. Chee J, et al. Effector-memory T cells develop in islets and report islet pathology in type 1 diabetes. J Immunol. 2014;192(2):572-580.

31. Graham KL, et al. Autoreactive cytotoxic T lymphocytes acquire higher expression of cytotoxic effector markers in the islets of NOD mice after priming in pancreatic lymph nodes. Am J Pathol. 2011;178(6):2716-2725.

32. Rigby MR, et al. Alefacept provides sustained clinical and immunological effects in newonset type 1 diabetes patients. JClin Invest. 2015;125(8):3285-3296.

33. Appay $\mathrm{V}$, et al. Memory $\mathrm{CD} 8^{+} \mathrm{T}$ cells vary in differentiation phenotype in different persistent virus infections. Nat Med. 2002;8(4):379-385.

34. Lalvani A, Brookes R, Hambleton S, Britton WJ, Hill AV, McMichael AJ. Rapid effector function in CD8 ${ }^{+}$memory T cells. J Exp Med 1997;186(6):859-865

35. Wherry EJ, Ahmed R. Memory CD8 T-cell differentiation during viral infection. J Virol. 2004;78(11):5535-5545.

36. Hislop AD, et al. EBV-specific $\mathrm{CD}^{+} \mathrm{T}$ cell memory: relationships between epitope specificity, cell phenotype, and immediate effector function. JImmunol. 2001;167(4):2019-2029.

37. Arif S, et al. $\beta$-Cell specific T-lymphocyte response has a distinct inflammatory phenotype in children with type 1 diabetes compared with adults. Diabet Med. 2017;34(3):419-425.

38. Wang EC, Taylor-Wiedeman J, Perera P, Fisher J, Borysiewicz LK. Subsets of $\mathrm{CD}^{+}, \mathrm{CD}^{+} 7^{+}$cells in normal, healthy individuals: correlations with 
human cytomegalovirus (HCMV) carrier status, phenotypic and functional analyses. Clin Exp Immunol. 1993;94(2):297-305.

39. Labalette M, Salez F, Pruvot FR, Noel C, Dessaint JP. CD8 lymphocytosis in primary cytomegalovirus (CMV) infection of allograft recipients: expansion of an uncommon $\mathrm{CD} 8^{+}$ CD57- subset and its progressive replacement by $\mathrm{CD} 8^{+} \mathrm{CD} 57^{+} \mathrm{T}$ cells. Clin Exp Immunol. 1994;95(3):465-471.

40. Leroy E, et al. Abnormally expanded $\mathrm{CD} 8^{+} /$ Leu- $7^{+}$lymphocytes persisting in long-term bone marrow-transplanted patients are resting pre-cytotoxic T-lymphocytes. Exp Hematol. 1990;18(7):770-774.

41. Madariaga L, et al. Induction of cytolytic function in resting peripheral blood $\mathrm{CD} 8^{+} / \mathrm{Leu}^{-7^{+}}$ T cells through IL2/p 75 IL2-receptor interaction: a study in the allogeneic human bone marrow transplantation model. Cell Immunol. 1990;130(2):291-302.

42. Vingerhoets JH, et al. Increased cytolytic T lymphocyte activity and decreased $\mathrm{B} 7$ responsiveness are associated with $\mathrm{CD} 28$ down-regulation on $\mathrm{CD} 8^{+} \mathrm{T}$ cells from HIV-infected subjects. Clin Exp Immunol. 1995;100(3):425-433.

43. Phillips JH, Lanier LL. Lectin-dependent and anti-CD3 induced cytotoxicity are preferentially mediated by peripheral blood cytotoxic $\mathrm{T}$ lymphocytes expressing Leu-7 antigen. J Immunol. 1986;136(5):1579-1585.

44. Papagno L, et al. Immune activation and $\mathrm{CD} 8^{+}$ $\mathrm{T}$-cell differentiation towards senescence in HIV-1 infection. PLoS Biol. 2004;2(2):E2O.

45. Appay V, van Lier RA, Sallusto F, Roederer M. Phenotype and function of human T lymphocyte subsets: consensus and issues. Cytometry $A$. 2008;73(11):975-983.

46. Mahnke YD, Brodie TM, Sallusto F, Roederer M, Lugli E. The who's who of T-cell differentiation: human memory T-cell subsets. Eur J Immunol. 2013;43(11):2797-2809.

47. Wherry EJ, Kurachi M. Molecular and cellular insights into T cell exhaustion. Nat Rev Immunol. 2015;15(8):486-499.

48. Brenchley JM, et al. Expression of CD57 defines replicative senescence and antigeninduced apoptotic death of $\mathrm{CD} 8^{+} \mathrm{T}$ cells. Blood. 2003;101(7):2711-2720.

49. Larbi A, Fulop T. From "truly naïve" to "exhausted senescent" T cells: when markers predict functionality. Cytometry A. 2014;85(1):25-35.

50. Strioga M, Pasukoniene V, Characiejus D. CD8 ${ }^{+}$ $\mathrm{CD} 28^{-}$and $\mathrm{CD} 8^{+} \mathrm{CD} 57^{+} \mathrm{T}$ cells and their role in health and disease. Immunology. 2011;134(1):17-32.

51. McKinney EF, Lee JC, Jayne DR, Lyons PA, Smith KG. T-cell exhaustion, co-stimulation and clinical outcome in autoimmunity and infection. Nature. 2015;523(7562):612-616.

52. Long SA, et al. Partial exhaustion of CD8 T cells and clinical response to teplizumab in new-onset type 1 diabetes. Sci Immunol. 2016;1(5):eaai7793.

53. d'Angeac AD, Monier S, Pilling D, TravaglioEncinoza A, Rème T, Salmon M. CD57 ${ }^{+}$T lymphocytes are derived from $\mathrm{CD} 57$ precursors by differentiation occurring in late immune responses. Eur J Immunol. 1994;24(7):1503-1511.

54. Pace $\mathrm{L}$, et al. The epigenetic control of stemness in $\mathrm{CD} 8^{+} \mathrm{T}$ cell fate commitment. Science. 2018;359(6372):177-186.

55 . Wooldridge $\mathrm{L}$, et al. Interaction between the CD8 coreceptor and major histocompatibility complex class I stabilizes $\mathrm{T}$ cell receptor-antigen complexes at the cell surface. J Biol Chem. 2005;280(30):27491-27501.

56. Lissina A, et al. Protein kinase inhibitors substantially improve the physical detection of T-cells with peptide-MHC tetramers. JImmunol Methods. 2009;340(1):11-24.

57. Tungatt K, et al. Antibody stabilization of peptideMHC multimers reveals functional $\mathrm{T}$ cells bearing extremely low-affinity TCRs. JImmunol. 2015;194(1):463-474.

58. Cernea S, Herold KC. Monitoring of antigenspecific CD8 T cells in patients with type 1 diabetes treated with antiCD3 monoclonal antibodies. Clin Immunol. 2010;134(2):121-129.

59. Luce $S$, et al. Single insulin-specific $\mathrm{CD} 8^{+} \mathrm{T}$ cells show characteristic gene expression profiles in human type 1 diabetes. Diabetes. 2011;60(12):3289-3299.

60. Velthuis JH, et al. Simultaneous detection of circulating autoreactive $\mathrm{CD} 8^{+} \mathrm{T}$-cells specific for different islet cell-associated epitopes using combinatorial MHC multimers. Diabetes. 2010;59(7):1721-1730.

61. Huber W, et al. Orchestrating high-throughput genomic analysis with Bioconductor. Nat Methods. 2015;12(2):115-121.

62. Orban T, et al. Reduction in CD4 central memory T-cell subset in costimulation modulator abatacept-treated patients with recent-onset type 1 diabetes is associated with slower C-peptide decline. Diabetes. 2014;63(10):3449-3457.

63. Johnson RA, Wichern DW. Applied multivariate statistical analysis. New York, New York, USA: Pearson; 2007. 